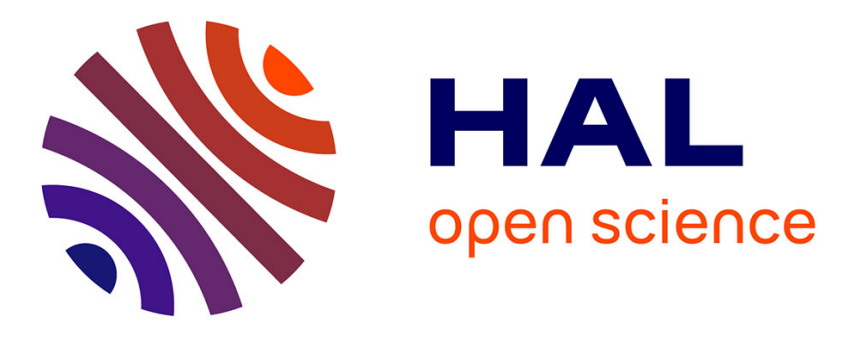

\title{
Blood-brain barrier, cytotoxic chemotherapies and glioblastoma
}

\author{
Antonin Dréan, Lauriane Goldwirt, Maïté Verreault, Michael Canney, \\ Charlotte Schmitt, Jeremy Guehennec, Jean-Yves Delattre, Alexandre \\ Carpentier, Ahmed Idbaih
}

\section{To cite this version:}

Antonin Dréan, Lauriane Goldwirt, Maïté Verreault, Michael Canney, Charlotte Schmitt, et al.. Blood-brain barrier, cytotoxic chemotherapies and glioblastoma. Expert Review of Neurotherapeutics, 2016, 16 (11), pp.1285 - 1300. 10.1080/14737175.2016.1202761 . hal-01414544

\section{HAL Id: hal-01414544 https://hal.sorbonne-universite.fr/hal-01414544}

Submitted on 12 Dec 2016

HAL is a multi-disciplinary open access archive for the deposit and dissemination of scientific research documents, whether they are published or not. The documents may come from teaching and research institutions in France or abroad, or from public or private research centers.
L'archive ouverte pluridisciplinaire HAL, est destinée au dépôt et à la diffusion de documents scientifiques de niveau recherche, publiés ou non, émanant des établissements d'enseignement et de recherche français ou étrangers, des laboratoires publics ou privés. 


\section{Blood-brain barrier, cytotoxic chemotherapies and glioblastoma}

Dréan Antonin ${ }^{1,2}$, Goldwirt Lauriane ${ }^{3}$, Verreault Maïté ${ }^{1}$, Canney Michael $^{2}$, Schmitt Charlotte ${ }^{1}$, Guehennec Jeremy ${ }^{1}$, Delattre Jean-Yves ${ }^{1,4}$, Carpentier Alexandre ${ }^{2,5}$ and Idbaih Ahmed ${ }^{1,4}$.

${ }^{1}$ Inserm U 1127, CNRS UMR 7225, Sorbonne Universités, UPMC Univ Paris 06 UMR S 1127, Institut du Cerveau et de la Moelle épinière, ICM, F-75013, Paris, France.

${ }^{2}$ Carthera SAS, Institut du Cerveau et de la Moelle épinière, ICM, F-75013, Paris, France.

${ }^{3}$ AP-HP, Hôpital Universitaire Saint Louis, Service de Pharmacologie, F-75013, Paris, France.

${ }^{4}$ AP-HP, Hôpital Universitaire La Pitié Salpêtrière, Service de Neurologie 2-Mazarin, F-75013, Paris, France.

${ }^{5}$ AP-HP, Hôpital Universitaire La Pitié Salpêtrière, Service de Neurochirurgie, F-75013, Paris, France.

\section{Corresponding author}

Ahmed Idbaih. Service de Neurologie 2-Mazarin, Groupe Hospitalier Pitié-Salpêtrière. 47-83, Boulevard de l'Hôpital, 75013 Paris, France. Tel: 01-42-16-03-85. Fax: 01-42-16-04-18. Email: ahmed.idbaih@gmail.com or ahmed.idbaih@aphp.fr

\section{Acknowledgments}

The research leading to these results has received funding from the program "Investissements d'avenir" ANR-10-IAIHU-06. Institut Universitaire de Cancérologie (IUC). Antonin Dréan is funded by Carthera SAS. This work is part of GlioTex (i.e. Glioblastoma and Experimental Therapeutics) project funded by La Fondation ARC pour la Recherche sur le Cancer 


\section{Abstract \\ Introduction.}

Glioblastoma (GBM) is the most common and aggressive primary malignant brain tumors in adults. The blood brain barrier (BBB) is a major limitation reducing efficacy of anti-cancer drugs in the treatment of GBM patients.

Areas covered.

Virtually all GBM recur after the first-line treatment, at least partly, due to invasive tumor cells protected, from chemotherapeutic agents, by the intact BBB in the brain adjacent to tumor. The passage, through the $\mathrm{BBB}$, by antitumor drugs is poorly and heterogeneously documented in the literature. In this review, we have focused our attention on: (i) the BBB, (ii) the passage of chemotherapeutic agents across the BBB and (iii) the strategies investigated to overcome this barrier.

Expert commentary.

A better preclinical knowledge of the crossing of the BBB by antitumor drugs will allow optimizing their clinical development, alone or combined with BBB bypassing strategies, towards an increased success rate of clinical trials.

Keywords: glioblastoma, blood-brain barrier, cytotoxic chemotherapy, pharmacokinetics, delivery. 


\section{Introduction}

Glioblastoma (GBM) is the most frequent primary brain cancer in adults. Indeed, GBM has an annual incidence from 0.6 to 3.7/100,000 individuals, with the highest incidences in European countries, United States, and Australia [1]. The median overall survival of newly diagnosed GBM patients is 12 to 18 months despite very intensive therapeutic regimens. The standard of care in newly diagnosed GBM patients, under 70 years old and in good clinical conditions, is maximal safe resection surgery followed by concurrent radiochemotherapy and adjuvant treatment with temozolomide (TMZ), an alkylating agent [2].

Virtually all GBM patients experience tumor recurrence. Several issues are known to limit the immediate and long-term efficacies of anti-cancer drugs in GBM: (i) the blood-brain barrier BBB- limiting penetration of drugs within the tumor and the brain adjacent to tumor -BAT-, (ii) primary or intrinsic molecular resistance, and (iii) secondary or acquired resistance after drug exposure.

In this review, we will focus on the BBB in the setting of primary brain cancers. Indeed, the $\mathrm{BBB}$ is a physical and biological barrier limiting drug penetration within the brain, and therefore within GBM cells. Although the BBB is disrupted in the tumor core, allowing a partial penetration of anti-tumor drugs, the $\mathrm{BBB}$ is widely intact around the BAT where invasive/escaping GBM cells can be found [3]. Reaching efficiently and safely these invasive/escaping GBM cells is one of the main challenges in GBM treatment, and developing strategies to overcome this limit will undoubtedly open new therapeutic perspectives using well-known cytotoxic drugs or innovative drugs.

In this review, we have focused our attention on: (i) the BBB, (ii) our knowledge of the passage of chemotherapeutic agents across the BBB and (iii) the strategies investigated to overcome this physico-biochemical barrier. 


\section{Methods}

Our review of public data was performed using: (i) Pubmed (http://www.ncbi.nlm.nih.gov/pubmed), (ii) Google (https://www.google.fr/), (iii) Google Scholar (https://scholar.google.fr/) and, (iv) University library.

Data related to the ability of drugs to cross the BBB were searched using the following formula (e.g. for CCNU): (CCNU OR belustine OR lomustine) AND ("brain/blood" OR "brain/plasma" OR "CSF/blood" OR "CSF/plasma" OR "brain:blood" OR "brain:plasma" OR "CSF:blood" OR "CSF:plasma") ratio.

Data related to the physicochemical characteristics of drugs were collected using public databases chEMBL (https://www.ebi.ac.uk/chembl/) and drugbank (http://www.drugbank.ca/) In silico data prediction was performed using http://www.cbligand.org/BBB/index.php.

Data related to cytotoxicity of anti-cancer drugs were collected from chEMBL database (https://www.ebi.ac.uk/chembl/).

The figures were made using the Servier Medical Art (http://www.servier.fr/smart/banquedimages-powerpoint.

\section{Brain barriers}

\subsection{The normal $B B B$}

The BBB is a physical and biological barrier: (i) protecting the brain from pathogens and toxic molecules circulating in the blood flow and, (ii) regulating hydrometabolic exchanges between the brain and blood to maintain brain homeostasis.

The BBB includes several cellular and molecular actors: (i) endothelial cells, (ii) pericytes, (iii) astrocytes, and (iv) extracellular matrix (Figure 1B). The barrier function of the BBB is mainly endorsed by the endothelial cells of blood vessels. The BBB functioning is also influenced by neurons, oligodendrocytes and microglial cells that belong to the neurovascular unit [4]. 
There are five main mechanisms or pathways driving molecular penetration through the BBB:

(i) passive paracellular pathway, (ii) transcellular lipophilic pathway, (iii) transcytosis pathway,

(iv) transport protein pathway, and (v) efflux pumps pathway (Figure 2).

Passive paracellular diffusion of molecules between endothelial cells is hampered by the tight junctions (TJ) and adherens junctions (AJ). Only few small highly liposoluble molecules can cross the BBB by passive paracellular diffusion [4].

Some small gaseous or lipophilic molecules are also able to cross the BBB by passive transcellular diffusion across endothelial cells themselves [4].

The transcytosis pathway refers to successive endocytosis from one side and exocytosis from the other side of endothelial cells. The three main transcytosis types are: (i) constitutive and non-specific -i.e. fluid-phase endocytosis: micropinocytosis, macropinocytosis-, (ii) ligand's charges mediated and non-specific -i.e. adsorptive endocytosis- and (iii) specific receptormediated. The non-specific transcytosis mechanisms are less represented in the BBB than in peripheral blood vessels $[4,5]$.

The transport protein pathway is an active and specific transport mechanism of molecules across the BBB. This transport pathway is predominant in the BBB. A large variety of transporters are expressed by endothelial cells including transporters from the solute carrier family (SLC). SLC2A1 (GLUT-1), involved in the crossing of glucose, is one of the most abundant transport of the SLC family [4,6,7].

The last mechanism is the efflux pumps pathway, a crucial mechanism for detoxification. Mainly ABCB1 (P-gp), ABCG2 (BCRP) and MRP 1 to 5 reject potential harmful xenobiotics from the endothelial cells to the blood (Figure 2) $[4,8]$.

The BBB is disrupted in restricted zones of the brain close to the $3^{\text {rd }}$ and the $4^{\text {th }}$ ventricles: the circumventricular organs. These organs are isolated from CSF by tightly attached ependymal 
cells (tanycytes) and from the brain by a dense layer of astrocytes, tanycytes and extracellular matrix [9-11] (figure 1E).

\subsection{The blood-tumor barrier}

In GBM, the tumor bulk is schematically organized in three major parts: (i) the necrotic central area, (ii) the proliferative/angiogenic forehead, and (iii) the BAT including invasive/escaping tumor cells (Figure 3).

The blood tumor barrier (BTB) refers to a histologically and/or biologically altered BBB with increased permeability. In the BTB, the blood vessels are anarchic, disorganized, sinuous, irregularly shaped, large and leaky, mainly due to an imperfect angiogenesis and inflammation $[12,13]$.

These modifications are due to both: (i) pro-angiogenic and immune-modulating factors secreted by GBM cells, and (ii) tumor-induced micro-environment changes [14-16].

\subsection{CSF-related barriers}

As discussed by Saunders et al., CSF is both isolated from the blood and the brain. In the ventricular system, CSF is isolated from the blood in the choroid plexus by epithelial cells that play a barrier role similar to the endothelial cells in the BBB (figure 1C). Even if the mechanisms are similar, specific transporters and efflux pumps are different from the ones expressed in the BBB $[17,18]$. Ependymal cells lining the ventricle are not tightly attached in adults. The ependyma is therefore not thought to hamper the diffusion from the CSF to the brain (figure 1C). However, transport systems and CSF flow limit diffusion to 1-2 mm [17,19]. CSF is also isolated from brain and blood by the arachnoid and pia matters that both present tightly packet cell layers that prevent diffusion from the blood to CSF and from CSF to the brain [20] (figure 1D). 


\section{The BBB limits drug penetration to both normal brain and tumors}

Currently, the most frequently used chemotherapy agent in GBM is temozolomide (TMZ), a drug that is able to cross the BBB [2]. Table 1 indicates several drugs according to their clinical use and their relevance in treatment of central nervous system (CNS) tumors.

Table 2 shows experimental brain and CSF penetration data for several drugs. Recently, Jacus et al. reviewed the pharmacokinetic properties of several anticancer agents, and assessed their penetration in CSF and/or in brain tissue of patients with CNS tumors [21].

Several physicochemical parameters are involved in the ability of drugs to cross the normal BBB: (i) size, (ii) liposolubility, (iii) charge, (iv) interactions with plasma proteins, and (v) interactions with efflux pumps and transporters. According to these parameters, several groups have suggested a way to predict in silico their ability to cross the BBB. The rule of 5 developed by Lipinski is the theoretical basis of these predictions [22]. According to this rule, "poor absorption or permeation is more likely when: (i) $>5$ hydrogen bond donors, (ii) MWt $>500$, (iii) $\log \mathrm{P}>5$, (iv) $>10$ hydrogen bond acceptors, and (v) substrates for biological transporters are exceptions to this rule". Although this modeling has been significantly improved over time, predictions are not always consistent with the experimental data [23]. Table 3 shows several parameters used for prediction of $\mathrm{BBB}$ crossing by drugs. As an example of the limits of predictive models, irinotecan is predicted not to cross the BBB and cisplatin is predicted to cross the BBB (Table 3), while the in vivo data reported in Table 2 shows that irinotecan is more likely to cross the BBB than cisplatin.

Predicting accurately the ability of anti-cancer drugs to cross the BBB and to penetrate in brain patients, based on our currents preclinical models, remains challenging. Combining in silico, in vitro and in vivo predicting approaches may help for better prediction. 


\section{Overcoming the BBB for better drug delivery within the tumor core and the BAT}

Table 4 indicates in vitro efficacy of chemotherapeutic cytotoxic agents investigated against GBM cells. Significant inter-laboratories variability is observed (e.g. the IC50 for paclitaxel on U87 cells ranges from 80 to $90000 \mathrm{nM}$ ). TMZ, the most commonly used chemotherapy agent in GBM, is inconsistently cytotoxic on GBM cell lines, while vincristine, vinblastine, paclitaxel and doxorubicin are up to $10,000-100,000$ times more cytotoxic than TMZ. Integrated therapeutic strategies including improved brain delivery of the most efficient drugs and molecular biomarkers of response to these drugs (e.g. MGMT for TMZ) will significantly improve the outcome for GBM patients [24]. Several approaches have been developed or are still under development.

\subsection{Intra-tumor injection}

Direct delivery of chemotherapy within the tumor and the BAT require insertion of a catheter within the tumor site. Imaging prior to drug administration is thus necessary to locate specifically the target site. Any molecule, regardless of its physicochemical characteristics, is deliverable using this method. The main limitations are local injuries: (i) infection, (ii) inflammatory reaction, and (iii) direct neurotoxicity (Table 1) [25,26]. Indeed, neurotoxicity of chemotherapeutic agents is a major issue when increasing local delivery (e.g. vincaalcaloids may induce seizure, encephalopathy, ataxia, and/or movement disorders; taxanes may induce seizure; and platinum derivatives may induce seizure, encephalopathy, stroke, ataxia and/or myelopathy) $[27,28]$. The main advantage of catheter-based drug delivery is an increase of local drug concentration without increasing systemic concentration and drug toxicity. The use of this method for nitrosoureas (i.e. BCNU and $\mathrm{CCNU}$ ) has shown efficacy and few side effects in mice and patients $[29,30]$. A stabilization of the tumor was observed for $72 \%$ of patients treated 
by DTI-015 (BCNU in 100\% ethanol) (NCT00038441) [29]. However, the invasiveness and the direct exposure of the brain to the drug toxicity limit the use of this method.

\subsection{Convection enhanced delivery (CED)}

Convection Enhanced Delivery (CED) is based on a catheter inserted, during a neurosurgical procedure, within the tumor or the BAT. The catheter is linked to an Ommaya/Rickham reservoir or to an external pump maintaining a positive pressure and flow. It allows a slow drug delivery over a longer period of time to reduce the potential acute neurotoxicity of chemotherapy [31]. CED has been tested for cisplatin, methotrexate, paclitaxel, nimustine, topotecan and carboplatin [32]. The capacity of a drug to diffuse within the brain parenchyma is heterogeneous and depends on : (i) the drug, (ii) the tumor site, and (iii) the administration parameters [32-35]. Cisplatin was reported to diffuse $1 \mathrm{~cm}$ around the needle tip in 1982 [36]. A more recent study indicated the mean volume of distribution is between 12.8 to $22.9 \mathrm{~cm}^{3}$ for paclitaxel [35]. Neurotoxicity was reported in some trials (e.g. paclitaxel). Despite the limitations of this invasive procedure, clinical benefits were observed brain tumor patients in some trials (e.g. nimustine, topotecan, carboplatin) [32]. Recently, an implantable catheter system was recently developed and tested with carboplatin in a recurrent GBM patient, and induced a 58\% tumor shrinkage and a stabilization of the patient's clinical condition (NCT01317212) [37].

\subsection{CSF delivery}

Drugs can be directly injected within the CSF. This method is mainly used to treat spinal cord tumors, leptomeningeal tumors, and tumor meningitis. As the CSF volume is lower than the blood volume, the intrathecal injection of chemotherapy leads to a higher concentration of chemotherapy, with a minimum risk of systemic toxicity [38]. However, the limited diffusion 
from CSF to the CNS parenchyma reduces the impact of this strategy in the treatment of intraparenchymal GBM patients [38]. Although some drugs are commonly used through the CSF route (e.g. methotrexate, cytarabine) with acceptable side effects, other drugs (e.g. vincristine) are contra-indicated for direct CSF delivery due to the high risk a severe neurotoxicity or death. $[39,40]$.

\subsection{In situ biodegradable polymer, gels, microships or microcarrier}

After surgical resection of the brain tumor, a cytotoxic agent-impregnated biodegradable polymer can be deposited in the tumor resection cavity. Carmustine impregnated wafers (Gliadel®) continuously deliver the drug directly in the brain parenchyma over 3 weeks [41]. Although initial results were promising, more recent data suggest a limited survival benefit in GBM patients (NCT00003876) [42-44]. Increasing drug concentration within the wafers might increase efficacy with acceptable toxicity as shown in a phase I clinical trial [45]. Adverse effects such as seizures, convulsions, confusion, brain edema, infection, hemiparesis, aphasia, and visual field defects were reported with this treatment [41-44,46,47]. High dose BCNU was detected 5 to $6.1 \mathrm{~mm}$ around the wafer on day 1 , and between 1.1 to $3.6 \mathrm{~mm}$ from days 3 to 30 . Several drugs were used within this delivery system. They were detected at low concentrations up to $5 \mathrm{~cm}$ around the wafer, but their concentration dropped below the LC90 (lethal concentration) within $1 \mathrm{~cm}$ around the wafer $[46,48,49]$. However, tumor recurrence was reported to occur mainly in the $2 \mathrm{~cm}$ around the BAT. The use of gels to fill the postsurgical cavity, micro-chips and micro-carriers instead of wafers has also been evaluated with quite similar efficacy and limitations mainly in murine models [50-53]. Gels have been investigated also in cancer patients (NCT00479765) [51]. 


\subsection{Transnasal epithelium drug delivery}

A drug can also cross the nasal epithelium at least in some regions of the brain [54], and reach CSF and brain. Transnasal drug delivery has been tested in animals for various treatments including methotrexate or 5-FU [54-56]. However, it has not been used in human to treat brain tumors so far.

5.6. High-dose and dose-dense chemotherapy delivered using intravenous (i.v.) peripheral route

As mentioned above, some drugs are very efficient against GBM cells in vitro, but exhibit limited effects in vivo due to their low ability to cross the BBB (e.g. doxorubicin, vincristine, vinblastine, paclitaxel). High-dose and dose-dense chemotherapy regimens aim, with or without bone marrow transplant, increasing drug concentrations within the brain tumor using higher dose of chemotherapy delivered in a peripheral vein. The benefits of these procedures, associated with significant toxicity, is debated and heterogeneous across patients (e.g. NCT00304031 and NCT01364064) [57-62].

\subsection{Intra-arterial (i.a.) drug delivery}

The i.a. delivery of drugs via the carotid artery has been shown to improve drug delivery within CNS. I.a. injection of cisplatin and etoposide led to a 2- and 4- fold increase of drug delivery to the brain compared to i.v. injection, respectively $[63,64]$. Penetration of methotrexate, aminoisobutyric acid and dextran 70 within the brain was 2 to 2.5 higher with i.a. delivery compared to i.v. delivery to tumor-bearing rats [65]. BCNU i.a. delivery achieved an 50-fold improvement of delivery in glioma patients [66]. ACNU i.a. delivery was not associated with an improvement of survival in glioma patients but showed a lower chemotherapy-related toxicity compared to $\mathrm{HeCNU}$ delivered by an i.a. injection. Overall, this route of injection is 
associated with a high risk of neurological, ophtalmological, and vascular toxicities limiting its use [67-73].

\subsection{Efflux pumps inhibition}

P-gp and BCRP can be inhibited by various drugs (e.g. cyclosporin A, elacridar, valspodar, tariquidar, or zosuquidar trihydrochloride) [74-76]. The association of paclitaxel and valspodar reduced the tumor volume up to $90 \%$, while paclitaxel alone had no effect. A prolonged 1.7 fold increase of brain concentration of paclitaxel was observed when combined with several of these inhibitors [77-79]. Colchicine and vinblastine uptake was enhanced 8.42- and 9.08-fold, respectively, when they were co-injected with valspodar in rats [80]. Cyclosporin A treatment also increases brain delivery of doxorubicin in rats [81]. However, cyclosporin A injection in non-human primates did not appear to improve the CSF delivery of doxorubicin [82]. Docetaxel brain concentration was also increased by elacridar, valspodar and cyclosporine $\mathrm{A}$ in mice [83]. Such inhibitors showed no or poor effect on different non-CNS tumors expressing P-gp in clinical trials enrolling patients (NCT00069160) [75]. However, due to the BBB and to high expression of efflux pumps in brain normal cells, this approach might be interesting. For example, combination of verapamil to an antiepileptic treatment in a patients with pharmacoresistant seizures doubled the time interval between hospitalizations, improved the overall control of seizures and the quality of life of patients [84]. An improved brain/plasma ratio was also obtained for loperamide when associated with tariquidar and elacridar [85]. Moreover, even if a method allows a molecule to cross the BBB, the therapeutic impact would be decreased by the efflux of the drug to the blood if it is substrate of efflux pumps [86]. Any method developed to delivery drugs to the brain could benefit the addition of an adjuvant efflux pumps inhibitors. 


\subsection{BBB opening}

Interestingly, beside their direct antitumor effect, some anti-tumor therapeutic strategies already used in clinics are able to open the BBB (e.g. etoposide, morphine and radiotherapy) [2,87-89]. The opening of the BBB can also be obtained by i.a. injection of hypotonic solutions or hyperosmotic solutions (i.e. mannitol). These two methods induce a water flow from the endothelial cells to the blood, leading to shrinkage and subsequent opening of TJs [90-92]. Interestingly, complete tumor response was reported for patients receiving carboplatin and etoposide after i.a. administration of mannitol [93]. Methotrexate, aminoisobutyric acid and dextran 70 delivery to the brain was improved by 2.5 to 7.6 fold by mannitol-induced BBB disruption [65]. In the same line, intra-carotid hyperosmolar perfusion in rats allowed 240$500 \%$ increase for antibodies [94]. Bradykinin or its agonist (i.e. RMP-7) or histamine also opens the BBB [95-97]. Intra-carotid infusion of RMP-7 improved the delivery of carboplatin by 2.7 fold in rats [98]. For methotrexate, aminoisobutyric acid and dextran 70, Neuwelt et al. reported an increase of drug delivery to the tumor and the BAT in rats by: (i) 2.2 to 2.5 -fold after i.a. injection compared to i.v. injection, (ii) 2.5 to 7.6 -fold after mannitol-induced BBB disruption compared to saline injection and, (iii) 6.3 to 16.7-fold combining both methods (i.a. + mannitol vs i.v. + saline) [65].

Ultrasounds can also be used to open the BBB $[92,99]$. Indeed, association of low frequency ultrasounds with microbubble contrast agents was shown to open the BBB, a technics that was described to be minimally/non-invasive and safe [100-102]. The ultrasound-induced opening of the $\mathrm{BBB}$ was reported to improve the TMZ CSF/plasma ratio from $22.7 \%$ to $38.6 \%$ in tumor bearing rats [103]. Irinotecan delivery was increased by $206 \%$ to $331 \%$ in healthy rabbits [104]. In a primate model, the mean platinum brain distribution was 5.2-fold higher in the US field (0$5 \mathrm{~mm}$ section) than in the contralateral hemisphere [105]. A phase I clinical trial (NCT02253212), testing non-focused ultrasounds plus carboplatin, is currently enrolling 
recurrent GBM patients. Thermal ablation of GBM on patients has also been performed with transcranial high-frequency focused ultrasound [106]. The use of the same device with different ultrasound parameters could therefore lead to a BBB opening [107].

\subsection{Drug design, modification and encapsulation}

Biochemical modifications (e.g. addition of ligand to receptor mediated transcytosis, lipophilic molecules, nanovectors and/or positively charged molecules) of existing drugs are explored to improve their capacity to cross the BBB and their anti-tumor efficacy.

Doxil $^{\circledR} /$ Caelix ${ }^{\circledR}$ consists of doxorubicin encapsulated in a PEGylated liposome. A stabilization in malignant gliomas patients was obtained with Doxil ${ }^{\circledR}[108]$. The modification of Doxil ${ }^{\circledR}$ with glutathione groups led to a 4.8 -fold increase of the brain-to-blood ratio compared to Doxil $^{\circledR} /$ Caelix $^{\circledR}(\sim 0.08 \%$ vs. $\sim 0.02 \%$ respectively) in preclinical models [109,110]. Various other methods have been tested, such as the modification of drugs with fatty acids to increase their liposolubility and to improve their diffusion through the BBB [111]. The modification of a drug with a molecule that is recognized by specific receptors/proteins on endothelial cells can also promote its passage through receptor mediated transcytosis (e.g. complexation of drugs with transferrin) $[5,112,113]$.

Interestingly, drug modification can be combined with other strategies to increase drug delivery within the brain, improve its stability, or reduce its elimination [114].

\subsection{Magnetic delivery}

Magnetic nanoparticles can be included in liposomes, forming thus magnetoliposomes. These magnetoliposomes can be modified with molecules such as transferrin to promote their interaction with the brain endothelium. Drugs can be loaded in these magnetoliposomes. Therefore, the application of a magnetic field around the brain can attract these particles out of 
the blood vessels, through the BBB, and deliver the drug in the brain parenchyma [115]. The use of paclitaxel-loaded anti-GPNMB antibodies-decorated magnetoliposomes improved the brain delivery of paclitaxel by 4 fold in rats. Paclitaxel concentration was still high $48 \mathrm{~h}$ after treatment for the liposomal form, while it was not detected after $6 \mathrm{~h}$ in animals treated with unmodified paclitaxel [116].

\subsection{Electric fields and Electromagnetic fields}

In 1977, application of low intensity electric fields to the brain was shown to induce BBB opening and to improve passage of dyes and drugs from the blood to the brain. This passage of drugs can also implicate multiple putative mechanisms : (i) iontophoresis (charge-mediated displacement of charged molecules), (ii) electro-osmotic, (iii) convection flows, and/or (iv) electroporation [117]. Recently, the use of intracranial irreversible electroporation in rats' brain was shown to induce a BBB opening [118].

The Novocure device delivers "tumor-treating fields" (TTF) to the brain, and was shown to induce tumor cells death in preclinics and to increase survival of newly diagnosed GBM patients (NCT00916409) [120]. The mechanism of tumor cells death remains unclear, but it is at least partly due to interaction of TTF with the cytoskeleton. Indeed, TTF impede polymerization and functions of tubulin resulting in abnormal mitoses and cytokinesis. Finally, the electroporation of tumor cells was also observed. Electroporation was proposed to explain the synergic effect of TTF and chemotherapy observed in some patients [120]. Moreover, a BBB opening was observed after non-thermal irreversible electroporation as a tumor ablation method [92]. Interactions between electromagnetic fields and BBB are still unclear and under investigations. [121].

\section{Discussion}


GBM is a lethal disease and more efficient therapeutic strategies are urgently needed. Despite the fact that multiple efficient cytotoxic chemotherapeutic agents are available, as demonstrated in in vitro preclinical models (i.e. GBM cell lines) and in vivo preclinical models without BBB (i.e. GBM subcutaneous xenografts), their efficacy is dramatically reduced in GBM orthotopic xenografts and in GBM patients [122]. Several reasons might explain this reduced efficacy in patients, one of them being the limited penetration of drugs within the tumor and the BAT.

The passage of cytotoxic drugs across the BBB is commonly admitted to be limited in patients and to be well-documented in the literature. However, data are scarce and heterogeneous in the literature, limiting comparisons across studies. Our review of the literature reports, in Table 2, the ability of anti-tumor drugs to cross the brain barriers (i.e. brain/plasma and CSF/plasma ratio). However, preclinical and clinical studies are heterogeneous in terms of material and methods: (i) heterogeneity of models and patients -tumor or not, tumor type, CNS involvement or not- and, (ii) heterogeneity of methods - i.e. route of administration of the drug, total dose, time between treatments, biological samples management, assays, cell lines used-. These heterogeneities, also raised by Jacus et al., highlight the difficulties to compare and to interpret studies in robust manner [21]. Therefore, major efforts need to be conducted by the community to standardize preclinical evaluation of drug efficacy and preclinical evaluation of drug penetration within the tumor, the BAT and the CSF.

Indeed, these data are critical to optimize drug delivery of current cytotoxic agents and to take advantage of efficient drugs that would be otherwise disregarded due to their incapacity to reach GBM cells. Indeed, one of the major therapeutic advances that have been accomplished over the last years in neuro-oncology came from very old cytotoxic drugs $[123,124]$. Therefore, "old drugs" might have unexpected efficacy if used in the right indication, in the right therapeutic regimen, at the right moment and in the right patients. 
Assessment of brain distribution is challenging in practice in preclinical and clinical settings. In silico prediction is the most efficient approach to perform a high throughput analysis. However, the limited accuracy of this method hampers the benefits of such evaluations. On a smaller scale, a limited number of molecules can also be analyzed using in vitro models of BBB. Various models exist, and they all rely on the transwell system. Endothelial cells are cultured on a porous membrane delimiting two compartments, representing the blood and the brain $[4,125]$. The drug can then be deposited in one compartment, and measured in the two compartments to quantify the passage of the drug. The most commonly used human endothelial cells are the immortalized human brain endothelial cells hCMEC/D3 cells [126]. These cells were shown to retain the normal gene expression pattern of endothelial cells of the BBB, making them one of the easiest to use, the most reproducible and the most reliable models. More accurate models are available but cannot be used in medium to large-scale studies [127]. The optimal animal model remains the non-human primate (e.g. Rhesus monkey). The BBB of rodents (mice, rats) is different from the human BBB. More specifically, the expression of efflux pumps such as ABCB1 (P-gp) and ABCG2 (BCRP) is qualitatively similar, but quantitatively different [128]. The pathway of in silico, preclinical in vitro, preclinical in vivo analysis allows preselection of the best candidate drugs at each step, and reduces the cost of drugs screening [129].

In clinical trials, most often, the passage of drugs is measured in the CSF. However, the drug concentration is not always well-correlated between the CSF and the brain. The most robust data are obtained with biopsies of the brain after chemotherapy administration. However, biopsies are mainly used for diagnosis rather than for drug dosage, and are thus performed prior to initiation of treatment. Phase 0 clinical trials may help to better understand CNS pharmacokinetics and pharmacodynamics of anti-cancer drugs [130]. 


\section{Expert commentary}

Treating brain diseases including glioblastoma is challenging due, at least partly, to the BBB. It will be virtually impossible to test, in human patients, for each anti-GBM candidate drug and for each drugs combination, their ability to cross the BBB, their therapeutic efficacy and their toxicity. Therefore, robust, reproducible and consensual models to assess the ability of antiGBM candidate drugs to cross the BBB in preclinical settings (i.e. in vitro and in vivo) needs to be optimized and validated-admitted across the research teams involved in the field. These models, including the complexity of the human $\mathrm{BBB}$, will undoubtedly better rationalize our selection of anti-GBM candidate drugs to be tested, alone or combined with a BBB-opening procedure, in clinical trials enrolling GBM patients. This strategy will improve our success rate in clinical trials dedicated to GBM patients and will benefit to GBM patients.

\section{Five-years view}

Currently, two major axis of therapeutic research are converging to increase efficacy of anti-cancer treatments in the field of primary malignant brain tumors. Innovative smart antitumor drugs are developed and some of them have demonstrated dramatic efficacy in systemic cancers raising hope in the treatment of GBM patients. Some of these promising drugs are large molecules (e.g. monoclonal antibodies) or highly hydrophilic. Obviously, although these anticancer drugs are efficient, they will not be able to reach GBM cells located in the BAT. Significant efforts are ongoing to increase, using chemical or physical approaches, bioavailability of these drugs with the GBM bulk and the BAT. Merging these two axis of therapeutic research will undoubtedly improve treatments of GBM patients.

\section{Conclusions}


The blood brain/tumor barrier is a major obstacle limiting efficacy of anti-cancer agents in GBM. Multiple classic cytotoxic agents and innovative drugs showed promising therapeutic activity in GBM cells in the absence of the BBB or BTB (i.e. in vitro experiments or subcutaneous xenografts). Their ability to cross the BBB and the BTB has been poorly or heterogeneously documented in the literature. A better comprehensive and standardize evaluation of the ability of drugs to cross the BBB and their anti-tumor efficacy is needed. In parallel, multiples innovative physical and chemical strategies are under development to bypass the $\mathrm{BBB}$ and the BTB particularly in the BAT. A better knowledge of the ability of drugs to cross the $\mathrm{BBB}$ and a better ability to open the BBB will undoubtedly improve treatments of GBM patients.

\section{Key issues}

- Escaping/invasive GBM cells, located in the BAT which is protected by intact BBB, are often the source of GBM recurrence

- The BBB remains a major obstacle to obtain therapeutic drug bio-availability within the GBM bulk and the BAT

- $\quad$ Systematic, comparable and comprehensive pharmacokinetics and pharmacodynamics data for anti-cancer drugs are lacking.

- $\quad$ Physical strategies to open the BBB in a reproducible, large, transient and safe are under investigations.

- Chemical strategies to increase drug penetration through the BBB are under investigations 


\section{References}

Papers of special note have been highlighted as:

* of interest

** of considerable interest

1. Ostrom QT, Bauchet L, Davis FG, et al. The epidemiology of glioma in adults: a "state of the science" review. Neuro-Oncol. 16(7), 896-913 (2014).

2. Stupp R, Mason WP, van den Bent MJ, et al. Radiotherapy plus concomitant and adjuvant temozolomide for glioblastoma. N. Engl. J. Med. 352(10), 987-996 (2005).

3. Scherer H. Structural development in gliomas. Am J Cancer., 333-351 (1938).

4. Wong AD, Ye M, Levy AF, Rothstein JD, Bergles DE, Searson PC. The blood-brain barrier: an engineering perspective. Front. Neuroengineering. 6, 7 (2013).

5. Preston JE, Joan Abbott N, Begley DJ. Transcytosis of macromolecules at the bloodbrain barrier. Adv. Pharmacol. San Diego Calif. 71, 147-163 (2014).

6. Shawahna R, Uchida Y, Declèves X, et al. Transcriptomic and quantitative proteomic analysis of transporters and drug metabolizing enzymes in freshly isolated human brain microvessels. Mol. Pharm. 8(4), 1332-1341 (2011).

7. Uchida Y, Ohtsuki S, Katsukura Y, et al. Quantitative targeted absolute proteomics of human blood-brain barrier transporters and receptors. J. Neurochem. 117(2), 333-345 (2011).

8. Hartz AMS, Bauer B. ABC transporters in the CNS - an inventory. Curr. Pharm. Biotechnol. 12(4), 656-673 (2011).

9. Horsburgh A, Massoud TF. The circumventricular organs of the brain: conspicuity on clinical 3T MRI and a review of functional anatomy. Surg. Radiol. Anat. SRA. 35(4), 343-349 (2013).

10. Langlet F, Mullier A, Bouret SG, Prevot V, Dehouck B. Tanycyte-like cells form a blood-cerebrospinal fluid barrier in the circumventricular organs of the mouse brain. $J$. Comp. Neurol. 521(15), 3389-3405 (2013).

11. Morita S, Furube E, Mannari T, et al. Heterogeneous vascular permeability and alternative diffusion barrier in sensory circumventricular organs of adult mouse brain. Cell Tissue Res. (2015).

12. Hillen F, Griffioen AW. Tumour vascularization: sprouting angiogenesis and beyond. Cancer Metastasis Rev. 26(3-4), 489-502 (2007).

13. Dubois LG, Campanati L, Righy C, et al. Gliomas and the vascular fragility of the blood brain barrier. Front. Cell. Neurosci. 8, 418 (2014). 
14. Lee J, Lund-Smith C, Borboa A, Gonzalez AM, Baird A, Eliceiri BP. Glioma-induced remodeling of the neurovascular unit. Brain Res. 1288, 125-134 (2009).

15. Schneider SW, Ludwig T, Tatenhorst L, et al. Glioblastoma cells release factors that disrupt blood-brain barrier features. Acta Neuropathol. (Berl.). 107(3), 272-276 (2004).

16. Wolburg H, Noell S, Fallier-Becker P, Mack AF, Wolburg-Buchholz K. The disturbed blood-brain barrier in human glioblastoma. Mol. Aspects Med. 33(5-6), 579-589 (2012).

17. de Lange ECM. Potential role of $\mathrm{ABC}$ transporters as a detoxification system at the blood-CSF barrier. Adv. Drug Deliv. Rev. 56(12), 1793-1809 (2004).

18. Saunders NR, Daneman R, Dziegielewska KM, Liddelow SA. Transporters of the bloodbrain and blood-CSF interfaces in development and in the adult. Mol. Aspects Med. 34(23), 742-752 (2013).

19. Pardridge WM. Drug transport in brain via the cerebrospinal fluid. Fluids Barriers CNS. 8(1), 7 (2011).

20. Patel N, Kirmi O. Anatomy and imaging of the normal meninges. Semin. Ultrasound. CT MR. 30(6), 559-564 (2009).

21. Jacus MO, Daryani VM, Harstead KE, Patel YT, Throm SL, Stewart CF. Pharmacokinetic Properties of Anticancer Agents for the Treatment of Central Nervous System Tumors: Update of the Literature. Clin. Pharmacokinet. (2015).

22. Lipinski CA, Lombardo F, Dominy BW, Feeney PJ. Experimental and computational approaches to estimate solubility and permeability in drug discovery and development settings. Adv. Drug Deliv. Rev. 46(1-3), 3-26 (2001).

23. Lanevskij K, Japertas P, Didziapetris R. Improving the prediction of drug disposition in the brain. Expert Opin. Drug Metab. Toxicol. 9(4), 473-486 (2013).

24. van Nifterik KA, van den Berg J, van der Meide WF, et al. Absence of the MGMT protein as well as methylation of the MGMT promoter predict the sensitivity for temozolomide. Br. J. Cancer. 103(1), 29-35 (2010).

25. Tomita T. Interstitial chemotherapy for brain tumors: review. J. Neurooncol. 10(1), 5774 (1991).

26. Oliver AS, Firth G, McKeran RO. Studies on the intracerebral injection of vincristine free and entrapped within liposomes in the rat. J. Neurol. Sci. 68(1), 25-30 (1985).

27. Stone JB, DeAngelis LM. Cancer-treatment-induced neurotoxicity--focus on newer treatments. Nat. Rev. Clin. Oncol. 13(2), 92-105 (2016).

28. Newton HB. Neurological complications of chemotherapy to the central nervous system. Handb. Clin. Neurol. 105, 903-916 (2012).

29. Hassenbusch SJ, Nardone EM, Levin VA, Leeds N, Pietronigro D. Stereotactic injection of DTI-015 into recurrent malignant gliomas: phase I/II trial. Neoplasia N. Y. N. 5(1), 9$16(2003)$. 
30. Tator $\mathrm{CH}$, Day A, Ng R, Liberman L. Chemotherapy of an experimental glioma with nitrosoureas. Cancer Res. 37(2), 476-481 (1977).

31. Ommaya AK. Subcutaneous reservoir and pump for sterile access to ventricular cerebrospinal fluid. Lancet. 2(7315), 983-984 (1963).

32. Healy AT, Vogelbaum MA. Convection-enhanced drug delivery for gliomas. Surg. Neurol. Int. 6(Suppl 1), S59-67 (2015).

33. Kroll RA, Pagel MA, Muldoon LL, Roman-Goldstein S, Neuwelt EA. Increasing volume of distribution to the brain with interstitial infusion: dose, rather than convection, might be the most important factor. Neurosurgery. 38(4), 746-752-754 (1996).

34. Sampson JH, Brady ML, Petry NA, et al. Intracerebral infusate distribution by convection-enhanced delivery in humans with malignant gliomas: descriptive effects of target anatomy and catheter positioning. Neurosurgery. 60(2 Suppl 1), ONS89-98-99 (2007).

35. Tanner PG, Holtmannspötter M, Tonn J-C, Goldbrunner R. Effects of drug efflux on convection-enhanced paclitaxel delivery to malignant gliomas: technical note. Neurosurgery. 61(4), E880-882; discussion E882 (2007).

36. Kroin JS, Penn RD. Intracerebral chemotherapy: chronic microinfusion of cisplatin. Neurosurgery. 10(3), 349-354 (1982).

37. Barua NU, Hopkins K, Woolley M, et al. A novel implantable catheter system with transcutaneous port for intermittent convection-enhanced delivery of carboplatin for recurrent glioblastoma. Drug Deliv. , 1-7 (2015).

38. Kerr JZ, Berg S, Blaney SM. Intrathecal chemotherapy. Crit. Rev. Oncol. Hematol. 37(3), 227-236 (2001).

39. Qweider M, Gilsbach JM, Rohde V. Inadvertent intrathecal vincristine administration: a neurosurgical emergency. Case report. J. Neurosurg. Spine. 6(3), 280-283 (2007).

40. Saiki JH, Thompson S, Smith F, Atkinson R. Paraplegia following intrathecal chemotherapy. Cancer. 29(2), 370-374 (1972).

41. Brem H, Mahaley MS, Vick NA, et al. Interstitial chemotherapy with drug polymer implants for the treatment of recurrent gliomas. J. Neurosurg. 74(3), 441-446 (1991).

42. Brem H, Piantadosi S, Burger PC, et al. Placebo-controlled trial of safety and efficacy of intraoperative controlled delivery by biodegradable polymers of chemotherapy for recurrent gliomas. The Polymer-brain Tumor Treatment Group. Lancet. 345(8956), 1008-1012 (1995).

43. Perry J, Chambers A, Spithoff K, Laperriere N. Gliadel wafers in the treatment of malignant glioma: a systematic review. Curr. Oncol. Tor. Ont. 14(5), 189-194 (2007).

44. Subach BR, Witham TF, Kondziolka D, Lunsford LD, Bozik M, Schiff D. Morbidity and survival after 1,3-bis(2-chloroethyl)-1-nitrosourea wafer implantation for recurrent 
glioblastoma: a retrospective case-matched cohort series. Neurosurgery. 45(1), 17-22-23 (1999).

45. Olivi A, Grossman SA, Tatter S, et al. Dose escalation of carmustine in surgically implanted polymers in patients with recurrent malignant glioma: a New Approaches to Brain Tumor Therapy CNS Consortium trial. J. Clin. Oncol. Off. J. Am. Soc. Clin. Oncol. 21(9), 1845-1849 (2003).

46. Engelhard HH. Tumor bed cyst formation after BCNU wafer implantation: report of two cases. Surg. Neurol. 53(3), 220-224 (2000).

47. Weber EL, Goebel EA. Cerebral edema associated with Gliadel wafers: Two case studies. Neuro-Oncol. 7(1), 84-89 (2005).

48. Fung LK, Shin M, Tyler B, Brem H, Saltzman WM. Chemotherapeutic drugs released from polymers: distribution of 1,3-bis(2-chloroethyl)-1-nitrosourea in the rat brain. Pharm. Res. 13(5), 671-682 (1996).

49. Fung LK, Ewend MG, Sills A, et al. Pharmacokinetics of interstitial delivery of carmustine, 4-hydroperoxycyclophosphamide, and paclitaxel from a biodegradable polymer implant in the monkey brain. Cancer Res. 58(4), 672-684 (1998).

50. Akbar U, Jones T, Winestone J, et al. Delivery of temozolomide to the tumor bed via biodegradable gel matrices in a novel model of intracranial glioma with resection. $J$. Neurooncol. 94(2), 203-212 (2009).

51. Elstad NL, Fowers KD. OncoGel (ReGel/paclitaxel)--clinical applications for a novel paclitaxel delivery system. Adv. Drug Deliv. Rev. 61(10), 785-794 (2009).

52. Kim GY, Tyler BM, Tupper MM, et al. Resorbable polymer microchips releasing BCNU inhibit tumor growth in the rat 9L flank model. J. Control. Release Off. J. Control. Release Soc. 123(2), 172-178 (2007).

53. Li KW, Dang W, Tyler BM, et al. Polilactofate microspheres for Paclitaxel delivery to central nervous system malignancies. Clin. Cancer Res. Off. J. Am. Assoc. Cancer Res. 9(9), 3441-3447 (2003).

54. Illum L. Transport of drugs from the nasal cavity to the central nervous system. Eur. J. Pharm. Sci. Off. J. Eur. Fed. Pharm. Sci. 11(1), 1-18 (2000).

55. Sakane T, Yamashita S, Yata N, Sezaki H. Transnasal Delivery of 5-Fluorouracil to the Brain in the Rat. J. Drug Target. 7(3), 233-240 (1999).

56. Shingaki T, Inoue D, Furubayashi T, et al. Transnasal delivery of methotrexate to brain tumors in rats: a new strategy for brain tumor chemotherapy. Mol. Pharm. 7(5), 15611568 (2010).

57. Bay J-O, Jacques-Olivier B, Linassier C, et al. Does high-dose carmustine increase overall survival in supratentorial high-grade malignant glioma? An EBMT retrospective study. Int. J. Cancer J. Int. Cancer. 120(8), 1782-1786 (2007). 
58. Grill J, Kalifa C, Doz F, et al. A high-dose busulfan-thiotepa combination followed by autologous bone marrow transplantation in childhood recurrent ependymoma. A phaseII study. Pediatr. Neurosurg. 25(1), 7-12 (1996).

59. Valteau-Couanet D, Fillipini B, Benhamou E, et al. High-dose busulfan and thiotepa followed by autologous stem cell transplantation (ASCT) in previously irradiated medulloblastoma patients: high toxicity and lack of efficacy. Bone Marrow Transplant. 36(11), 939-945 (2005).

60. Armstrong TS, Wefel JS, Wang M, et al. Net clinical benefit analysis of radiation therapy oncology group 0525: a phase III trial comparing conventional adjuvant temozolomide with dose-intensive temozolomide in patients with newly diagnosed glioblastoma. $J$. Clin. Oncol. Off. J. Am. Soc. Clin. Oncol. 31(32), 4076-4084 (2013).

61. Gilbert MR, Wang M, Aldape KD, et al. Dose-dense temozolomide for newly diagnosed glioblastoma: a randomized phase III clinical trial. J. Clin. Oncol. Off. J. Am. Soc. Clin. Oncol. 31(32), 4085-4091 (2013).

62. Massimino M, Gandola L, Luksch R, et al. Sequential chemotherapy, high-dose thiotepa, circulating progenitor cell rescue, and radiotherapy for childhood high-grade glioma. Neuro-Oncol. 7(1), 41-48 (2005).

63. Nakagawa H, Fujita T, Izumoto S, et al. cis-diamminedichloroplatinum (CDDP) therapy for brain metastasis of lung cancer. I. Distribution within the central nervous system after intravenous and intracarotid infusion. J. Neurooncol. 16(1), 61-67 (1993).

64. Savaraj N, Lu K, Feun LG, Burgess MA, Loo TL. Comparison of CNS penetration, tissue distribution, and pharmacology of VP 16-213 by intracarotid and intravenous administration in dogs. Cancer Invest. 5(1), 11-16 (1987).

65. Neuwelt EA, Barnett PA, McCormick CI, Remsen LG, Kroll RA, Sexton G. Differential permeability of a human brain tumor xenograft in the nude rat: impact of tumor size and method of administration on optimizing delivery of biologically diverse agents. Clin. Cancer Res. Off. J. Am. Assoc. Cancer Res. 4(6), 1549-1555 (1998).

66. Tyler JL, Yamamoto YL, Diksic M, et al. Pharmacokinetics of superselective intraarterial and intravenous [11C]BCNU evaluated by PET. J. Nucl. Med. Off. Publ. Soc. Nucl. Med. 27(6), 775-780 (1986).

67. Chauveinc L, Sola-Martinez MT, Martin-Duverneuil M, et al. Intra arterial chemotherapy with ACNU and radiotherapy in inoperable malignant gliomas. $J$. Neurooncol. 27(2), 141-147 (1996).

68. Hirano Y, Mineura K, Mizoi K, Tomura N. Therapeutic results of intra-arterial chemotherapy in patients with malignant glioma. Int. J. Oncol. 13(3), 537-542 (1998).

69. Imbesi F, Marchioni E, Benericetti E, et al. A randomized phase III study: comparison between intravenous and intraarterial ACNU administration in newly diagnosed primary glioblastomas. Anticancer Res. 26(1B), 553-558 (2006). 
70. Kochii M, Kitamura I, Goto T, et al. Randomized comparison of intra-arterial versus intravenous infusion of ACNU for newly diagnosed patients with glioblastoma. $J$. Neurooncol. 49(1), 63-70 (2000).

71. Poisson M, Chiras J, Fauchon F, Delattre JY. [Treatment of supratentorial glioma in adults by intra-arterial HECNU. Experience of the Pitié-Salpétrière group]. Rev. Neurol. (Paris). 148(6-7), 441-447 (1992).

72. Roosen N, Lins E, Kiwit JC, Schirmer M, Bock WJ. Intra-arterial chemotherapy with ACNU for the treatment of glioblastoma. Preliminary experience. Acta Radiol. Suppl. 369, 220-222 (1986).

73. Vega F, Davila L, Chatellier G, et al. Treatment of malignant gliomas with surgery, intraarterial chemotherapy with ACNU and radiation therapy. J. Neurooncol. 13(2), 131135 (1992).

74. Bankstahl JP, Bankstahl M, Römermann K, et al. Tariquidar and elacridar are dosedependently transported by P-glycoprotein and Bcrp at the blood-brain barrier: a smallanimal positron emission tomography and in vitro study. Drug Metab. Dispos. Biol. Fate Chem. 41(4), 754-762 (2013).

75. Fox E, Bates SE. Tariquidar (XR9576): a P-glycoprotein drug efflux pump inhibitor. Expert Rev. Anticancer Ther. 7(4), 447-459 (2007).

76. International Transporter Consortium, Giacomini KM, Huang S-M, et al. Membrane transporters in drug development. Nat. Rev. Drug Discov. 9(3), 215-236 (2010).

77. Kemper EM, Cleypool C, Boogerd W, Beijnen JH, van Tellingen O. The influence of the P-glycoprotein inhibitor zosuquidar trihydrochloride (LY335979) on the brain penetration of paclitaxel in mice. Cancer Chemother. Pharmacol. 53(2), 173-178 (2004).

78. Kemper EM, van Zandbergen AE, Cleypool C, et al. Increased penetration of paclitaxel into the brain by inhibition of P-Glycoprotein. Clin. Cancer Res. Off. J. Am. Assoc. Cancer Res. 9(7), 2849-2855 (2003).

79. Fellner S, Bauer B, Miller DS, et al. Transport of paclitaxel (Taxol) across the bloodbrain barrier in vitro and in vivo. J. Clin. Invest. 110(9), 1309-1318 (2002).

80. Drion N, Lemaire M, Lefauconnier JM, Scherrmann JM. Role of P-glycoprotein in the blood-brain transport of colchicine and vinblastine. J. Neurochem. 67(4), 1688-1693 (1996).

81. Hughes CS, Vaden SL, Manaugh CA, Price GS, Hudson LC. Modulation of doxorubicin concentration by cyclosporin $\mathrm{A}$ in brain and testicular barrier tissues expressing Pglycoprotein in rats. J. Neurooncol. 37(1), 45-54 (1998).

82. Warren KE, Patel MC, McCully CM, Montuenga LM, Balis FM. Effect of Pglycoprotein modulation with cyclosporin A on cerebrospinal fluid penetration of doxorubicin in non-human primates. Cancer Chemother. Pharmacol. 45(3), 207-212 (2000). 
83. Kemper EM, Verheij M, Boogerd W, Beijnen JH, van Tellingen O. Improved penetration of docetaxel into the brain by co-administration of inhibitors of P-glycoprotein. Eur. J. Cancer Oxf. Engl. 1990. 40(8), 1269-1274 (2004).

84. Asadi-Pooya AA, Razavizadegan SMA, Abdi-Ardekani A, Sperling MR. Adjunctive use of verapamil in patients with refractory temporal lobe epilepsy: a pilot study. Epilepsy Behav. EB. 29(1), 150-154 (2013).

85. Choo EF, Kurnik D, Muszkat M, et al. Differential in vivo sensitivity to inhibition of Pglycoprotein located in lymphocytes, testes, and the blood-brain barrier. J. Pharmacol. Exp. Ther. 317(3), 1012-1018 (2006).

86. Mason WP. Blood-brain barrier-associated efflux transporters: a significant but underappreciated obstacle to drug development in glioblastoma. Neuro-Oncol. 17(9), 1181-1182 (2015).

87. Hollis PH, Zappulla RA, Spigelman MK, et al. Physiological and electrophysiological consequences of etoposide-induced blood-brain barrier disruption. Neurosurgery. 18(5), 581-586 (1986).

88. Sardi I. Morphine facilitates doxorubicin penetration in the central nervous system: a new prospect for therapy of brain tumors. J. Neurooncol. 104(2), 619-620 (2011).

89. Cao Y, Tsien CI, Shen Z, et al. Use of magnetic resonance imaging to assess bloodbrain/blood-glioma barrier opening during conformal radiotherapy. J. Clin. Oncol. Off. J. Am. Soc. Clin. Oncol. 23(18), 4127-4136 (2005).

90. Rapoport SI, Robinson PJ. Tight-junctional modification as the basis of osmotic opening of the blood-brain barrier. Ann. N. Y. Acad. Sci. 481, 250-267 (1986).

91. Joshi S, Ergin A, Wang M, et al. Inconsistent blood brain barrier disruption by intraarterial mannitol in rabbits: implications for chemotherapy. J. Neurooncol. 104(1), 11-19 (2011).

92. Rodriguez A, Tatter SB, Debinski W. Neurosurgical Techniques for Disruption of the Blood-Brain Barrier for Glioblastoma Treatment. Pharmaceutics. 7(3), 175-187 (2015).

93. Neuwelt EA, Wiliams PC, Mickey BE, Frenkel EP, Henner WD. Therapeutic dilemma of disseminated CNS germinoma and the potential of increased platinum-based chemotherapy delivery with osmotic blood-brain barrier disruption. Pediatr. Neurosurg. 21(1), 16-22 (1994).

94. Bullard DE, Bourdon M, Bigner DD. Comparison of various methods for delivering radiolabeled monoclonal antibody to normal rat brain. J. Neurosurg. 61(5), 901-911 (1984).

95. Gregor A, Lind M, Newman H, et al. Phase II studies of RMP-7 and carboplatin in the treatment of recurrent high grade glioma. RMP-7 European Study Group. J. Neurooncol. 44(2), 137-145 (1999).

96. Prados MD, Schold SC JR SC, Fine HA, et al. A randomized, double-blind, placebocontrolled, phase 2 study of RMP-7 in combination with carboplatin administered 
intravenously for the treatment of recurrent malignant glioma. Neuro-Oncol. 5(2), 96103 (2003).

97. Qureshi AI, Suri MF, Khan J, et al. Superselective intra-arterial carboplatin for treatment of intracranial neoplasms: experience in 100 procedures. J. Neurooncol. 51(2), 151-158 (2001).

98. Matsukado K, Inamura T, Nakano S, Fukui M, Bartus RT, Black KL. Enhanced tumor uptake of carboplatin and survival in glioma-bearing rats by intracarotid infusion of bradykinin analog, RMP-7. Neurosurgery. 39(1), 125-133-134 (1996).

99. Vykhodtseva NI, Hynynen K, Damianou C. Histologic effects of high intensity pulsed ultrasound exposure with subharmonic emission in rabbit brain in vivo. Ultrasound Med. Biol. 21(7), 969-979 (1995).

100. Horodyckid C, Canney M, Vignot A, et al. Safe long-term repeated disruption of the blood-brain barrier using an implantable ultrasound device : a multiparametric study in primates. J Neurosurg. (2015).

101. McDannold N, Vykhodtseva N, Raymond S, Jolesz FA, Hynynen K. MRI-guided targeted blood-brain barrier disruption with focused ultrasound: histological findings in rabbits. Ultrasound Med. Biol. 31(11), 1527-1537 (2005).

102. Hynynen K, McDannold N, Sheikov NA, Jolesz FA, Vykhodtseva N. Local and reversible blood-brain barrier disruption by noninvasive focused ultrasound at frequencies suitable for trans-skull sonications. NeuroImage. 24(1), 12-20 (2005).

103. Wei K-C, Chu P-C, Wang H-YJ, et al. Focused ultrasound-induced blood-brain barrier opening to enhance temozolomide delivery for glioblastoma treatment: a preclinical study. PloS One. 8(3), e58995 (2013).

104. Beccaria K, Canney M, Goldwirt L, et al. Ultrasound-induced opening of the blood-brain barrier to enhance temozolomide and irinotecan delivery: an experimental study in rabbits. J. Neurosurg. , 1-9 (2015).

105. Goldwirt L, Canney M, Horodyckid C, et al. Enhanced brain distribution of carboplatin in a primate model after blood-brain barrier disruption using an implantable ultrasound device. Cancer Chemother. Pharmacol. (2015).

106. McDannold N, Clement GT, Black P, Jolesz F, Hynynen K. Transcranial magnetic resonance imaging- guided focused ultrasound surgery of brain tumors: initial findings in 3 patients. Neurosurgery. 66(2), 323-332; discussion 332 (2010).

107. McDannold N, Arvanitis CD, Vykhodtseva N, Livingstone MS. Temporary disruption of the blood-brain barrier by use of ultrasound and microbubbles: safety and efficacy evaluation in rhesus macaques. Cancer Res. 72(14), 3652-3663 (2012).

108. Fabel K, Dietrich J, Hau P, et al. Long-term stabilization in patients with malignant glioma after treatment with liposomal doxorubicin. Cancer. 92(7), 1936-1942 (2001).

109. Birngruber T, Raml R, Gladdines W, et al. Enhanced doxorubicin delivery to the brain administered through glutathione PEGylated liposomal doxorubicin (2B3-101) as 
compared with generic Caelyx,(®)/Doxil(@)--a cerebral open flow microperfusion pilot study. J. Pharm. Sci. 103(7), 1945-1948 (2014).

110. Gaillard PJ, Appeldoorn CCM, Dorland R, et al. Pharmacokinetics, brain delivery, and efficacy in brain tumor-bearing mice of glutathione pegylated liposomal doxorubicin (2B3-101). PloS One. 9(1), e82331 (2014).

111. Bradley MO, Webb NL, Anthony FH, et al. Tumor targeting by covalent conjugation of a natural fatty acid to paclitaxel. Clin. Cancer Res. Off. J. Am. Assoc. Cancer Res. 7(10), 3229-3238 (2001).

112. Lajoie JM, Shusta EV. Targeting receptor-mediated transport for delivery of biologics across the blood-brain barrier. Annu. Rev. Pharmacol. Toxicol. 55, 613-631 (2015).

113. Zhang F, Xu C-L, Liu C-M. Drug delivery strategies to enhance the permeability of the blood-brain barrier for treatment of glioma. Drug Des. Devel. Ther. 9, 2089-2100 (2015).

114. Fan C-H, Ting C-Y, Lin H-J, et al. SPIO-conjugated, doxorubicin-loaded microbubbles for concurrent MRI and focused-ultrasound enhanced brain-tumor drug delivery. Biomaterials. 34(14), 3706-3715 (2013).

115. Thomsen LB, Thomsen MS, Moos T. Targeted drug delivery to the brain using magnetic nanoparticles. Ther. Deliv. (2015).

116. Dilnawaz F, Singh A, Mewar S, Sharma U, Jagannathan NR, Sahoo SK. The transport of non-surfactant based paclitaxel loaded magnetic nanoparticles across the blood brain barrier in a rat model. Biomaterials. 33(10), 2936-2951 (2012).

117. Mitragotri S. Devices for overcoming biological barriers: the use of physical forces to disrupt the barriers. Adv. Drug Deliv. Rev. 65(1), 100-103 (2013).

118. Garcia PA, Rossmeisl JH, Robertson JL, et al. 7.0-T magnetic resonance imaging characterization of acute blood-brain-barrier disruption achieved with intracranial irreversible electroporation. PloS One. 7(11), e50482 (2012).

119. Stupp R, Taillibert S, Kanner AA, et al. Maintenance therapy with tumor-treating fields plus temozolomide vs temozolomide alone for glioblastoma: A randomized clinical trial. JAMA. 314(23), 2535-2543 (2015).

120. Rehman AA, Elmore KB, Mattei TA. The effects of alternating electric fields in glioblastoma: current evidence on therapeutic mechanisms and clinical outcomes. Neurosurg. Focus. 38(3), E14 (2015).

121. Stam R. Electromagnetic fields and the blood-brain barrier. Brain Res. Rev. 65(1), 8097 (2010).

122. Pokorny JL, Calligaris D, Gupta SK, et al. The Efficacy of the Wee1 Inhibitor MK-1775 Combined with Temozolomide Is Limited by Heterogeneous Distribution across the Blood-Brain Barrier in Glioblastoma. Clin. Cancer Res. 21(8), 1916-1924 (2015).

123. van den Bent MJ, Brandes AA, Taphoorn MJB, et al. Adjuvant procarbazine, lomustine, and vincristine chemotherapy in newly diagnosed anaplastic oligodendroglioma: long- 
term follow-up of EORTC brain tumor group study 26951. J. Clin. Oncol. Off. J. Am. Soc. Clin. Oncol. 31(3), 344-350 (2013).

124. Cairncross G, Wang M, Shaw E, et al. Phase III trial of chemoradiotherapy for anaplastic oligodendroglioma: long-term results of RTOG 9402. J. Clin. Oncol. Off. J. Am. Soc. Clin. Oncol. 31(3), 337-343 (2013).

125. Naik P, Cucullo L. In vitro blood-brain barrier models: current and perspective technologies. J. Pharm. Sci. 101(4), 1337-1354 (2012).

126. Weksler BB, Subileau EA, Perrière N, et al. Blood-brain barrier-specific properties of a human adult brain endothelial cell line. FASEB J. Off. Publ. Fed. Am. Soc. Exp. Biol. 19(13), 1872-1874 (2005).

127. Garberg P, Ball M, Borg N, et al. In vitro models for the blood-brain barrier. Toxicol. Vitro Int. J. Publ. Assoc. BIBRA. 19(3), 299-334 (2005).

128. Warren MS, Zerangue N, Woodford K, et al. Comparative gene expression profiles of ABC transporters in brain microvessel endothelial cells and brain in five species including human. Pharmacol. Res. Off. J. Ital. Pharmacol. Soc. 59(6), 404-413 (2009).

129. Abbott NJ. Prediction of blood-brain barrier permeation in drug discovery from in vivo, in vitro and in silico models. Drug Discov. Today Technol. 1(4), 407-416 (2004).

130. Sigmond J, Honeywell RJ, Postma TJ, et al. Gemcitabine uptake in glioblastoma multiforme: potential as a radiosensitizer. Ann. Oncol. 20(1), 182-187 (2009).

131. Langlet F. [Role of tanycytes within the blood-hypothalamus interface]. Biol. Aujourdhui. 208(3), 225-235 (2014).

132. Cherubini GB, Platt S. Neurological complications of chemotherapy. Companion Anim. 13(5), 76-82 (2008).

133. Taal W, Oosterkamp HM, Walenkamp AME, et al. Single-agent bevacizumab or lomustine versus a combination of bevacizumab plus lomustine in patients with recurrent glioblastoma (BELOB trial): a randomised controlled phase 2 trial. Lancet Oncol. 15(9), 943-953 (2014).

134. Brada M, Hoang-Xuan K, Rampling R, et al. Multicenter phase II trial of temozolomide in patients with glioblastoma multiforme at first relapse. Ann. Oncol. Off. J. Eur. Soc. Med. Oncol. ESMO. 12(2), 259-266 (2001).

135. Malmström A, Grønberg BH, Marosi C, et al. Temozolomide versus standard 6-week radiotherapy versus hypofractionated radiotherapy in patients older than 60 years with glioblastoma: the Nordic randomised, phase 3 trial. Lancet Oncol. 13(9), 916-926 (2012).

136. Paulsen F, Hoffmann W, Becker G, et al. Chemotherapy in the treatment of recurrent glioblastoma multiforme: ifosfamide versus temozolomide. J. Cancer Res. Clin. Oncol. 125(7), 411-418 (1999). 
137. Luyendijk W, van Beusekom GT. Chemotherapy of cerebral gliomas with intra-carotid methotrexate-infusion. Acta Neurochir. (Wien). 15(3), 234-248 (1966).

138. Bruce JN, Fine RL, Canoll P, et al. Regression of recurrent malignant gliomas with convection-enhanced delivery of topotecan. Neurosurgery. 69(6), 1272-1279-1280 (2011).

139. Macdonald D, Cairncross G, Stewart D, et al. Phase II study of topotecan in patients with recurrent malignant glioma. National Clinical Institute of Canada Clinical Trials Group. Ann. Oncol. Off. J. Eur. Soc. Med. Oncol. ESMO. 7(2), 205-207 (1996).

140. Fulton D, Urtasun R, Forsyth P. Phase II study of prolonged oral therapy with etoposide (VP16) for patients with recurrent malignant glioma. J. Neurooncol. 27(2), 149-155 (1996).

141. Friedman HS, Petros WP, Friedman AH, et al. Irinotecan therapy in adults with recurrent or progressive malignant glioma. J. Clin. Oncol. Off. J. Am. Soc. Clin. Oncol. 17(5), 1516-1525 (1999).

142. Prados MD, Lamborn K, Yung WKA, et al. A phase 2 trial of irinotecan (CPT-11) in patients with recurrent malignant glioma: a North American Brain Tumor Consortium study. Neuro-Oncol. 8(2), 189-193 (2006).

143. Turner CD, Gururangan S, Eastwood J, et al. Phase II study of irinotecan (CPT-11) in children with high-risk malignant brain tumors: the Duke experience. Neuro-Oncol. 4(2), 102-108 (2002).

144. Cloughesy TF, Gobin YP, Black KL, et al. Intra-arterial carboplatin chemotherapy for brain tumors: a dose escalation study based on cerebral blood flow. J. Neurooncol. 35(2), 121-131 (1997).

145. Prados MD, Warnick RE, Mack EE, et al. Intravenous carboplatin for recurrent gliomas. A dose-escalating phase II trial. Am. J. Clin. Oncol. 19(6), 609-612 (1996).

146. Stewart DJ, Belanger JM, Grahovac Z, et al. Phase I study of intracarotid administration of carboplatin. Neurosurgery. 30(4), 512-516-517 (1992).

147. Yung WK, Albright RE, Olson J, et al. A phase II study of temozolomide vs. procarbazine in patients with glioblastoma multiforme at first relapse. Br. J. Cancer. 83(5), 588-593 (2000).

148. Chamberlain MC, Kormanik P. Salvage chemotherapy with paclitaxel for recurrent primary brain tumors. J. Clin. Oncol. Off. J. Am. Soc. Clin. Oncol. 13(8), 2066-2071 (1995).

149. Lidar Z, Mardor Y, Jonas T, et al. Convection-enhanced delivery of paclitaxel for the treatment of recurrent malignant glioma: a phase I/II clinical study. J. Neurosurg. 100(3), 472-479 (2004).

150. Postma TJ, Heimans JJ, Luykx SA, et al. A phase II study of paclitaxel in chemonaïve patients with recurrent high-grade glioma. Ann. Oncol. Off. J. Eur. Soc. Med. Oncol. ESMO. 11(4), 409-413 (2000). 
151. Fabrini MG, Silvano G, Lolli I, et al. A multi-institutional phase II study on second-line Fotemustine chemotherapy in recurrent glioblastoma. J. Neurooncol. 92(1), 79-86 (2009).

152. Khayat D, Giroux B, Berille J, et al. Fotemustine in the treatment of brain primary tumors and metastases. Cancer Invest. 12(4), 414-420 (1994).

153. Pennese E, Vergine C, Matera R, Dargenio M, Forese P, Di Renzo N. Complete response induced by fotemustine given as single agent in a patient with primary central nervous system non-Hodgkin aggressive lymphoma relapsed after high-dose chemotherapy and autologous stem cell support. Leuk. Lymphoma. 52(11), 2188-2189 (2011).

154. Tranchand B, Lucas C, Biron P, et al. Phase I pharmacokinetics study of high-dose fotemustine and its metabolite 2-chloroethanol in patients with high-grade gliomas. Cancer Chemother. Pharmacol. 32(1), 46-52 (1993).

155. Dirven L, van den Bent MJ, Bottomley A, et al. The impact of bevacizumab on healthrelated quality of life in patients treated for recurrent glioblastoma: results of the randomised controlled phase 2 BELOB trial. Eur. J. Cancer Oxf. Engl. 1990. 51(10), 1321-1330 (2015).

156. Friedman HS, Prados MD, Wen PY, et al. Bevacizumab alone and in combination with irinotecan in recurrent glioblastoma. J. Clin. Oncol. Off. J. Am. Soc. Clin. Oncol. 27(28), 4733-4740 (2009).

157. Kreisl TN, Kim L, Moore K, et al. Phase II trial of single-agent bevacizumab followed by bevacizumab plus irinotecan at tumor progression in recurrent glioblastoma. J. Clin. Oncol. Off. J. Am. Soc. Clin. Oncol. 27(5), 740-745 (2009).

158. Nagane M, Nishikawa R, Narita Y, et al. Phase II study of single-agent bevacizumab in Japanese patients with recurrent malignant glioma. Jpn. J. Clin. Oncol. 42(10), 887-895 (2012).

159. Patchell RA, Regine WF, Ashton P, et al. A phase I trial of continuously infused intratumoral bleomycin for the treatment of recurrent glioblastoma multiforme. $J$. Neurooncol. 60(1), 37-42 (2002).

160. Dresemann G, Weller M, Rosenthal MA, et al. Imatinib in combination with hydroxyurea versus hydroxyurea alone as oral therapy in patients with progressive pretreated glioblastoma resistant to standard dose temozolomide. J. Neurooncol. 96(3), 393-402 (2010).

161. Forsyth P, Cairncross G, Stewart D, Goodyear M, Wainman N, Eisenhauer E. Phase II trial of docetaxel in patients with recurrent malignant glioma: a study of the National Cancer Institute of Canada Clinical Trials Group. Invest. New Drugs. 14(2), 203-206 (1996).

162. Sanson M, Napolitano M, Yaya R, et al. Second line chemotherapy with docetaxel in patients with recurrent malignant glioma: a phase II study. J. Neurooncol. 50(3), 245249 (2000). 
163. Zwerdling T, Krailo M, Monteleone $\mathrm{P}$, et al. Phase II investigation of docetaxel in pediatric patients with recurrent solid tumors: a report from the Children's Oncology Group. Cancer. 106(8), 1821-1828 (2006).

164. Hassan M, Ehrsson H, Wallin I, Eksborg S. Pharmacokinetic and metabolic studies of busulfan in rat plasma and brain. Eur. J. Drug Metab. Pharmacokinet. 13(4), 301-305 (1988).

165. Hassan M, Ehrsson H, Smedmyr B, et al. Cerebrospinal fluid and plasma concentrations of busulfan during high-dose therapy. Bone Marrow Transplant. 4(1), 113-114 (1989).

166. Hassan M, Hassan Z, Nilsson C, et al. Pharmacokinetics and distribution of liposomal busulfan in the rat: a new formulation for intravenous administration. Cancer Chemother. Pharmacol. 42(6), 471-478 (1998).

167. Vassal G, Gouyette A, Hartmann O, Pico JL, Lemerle J. Pharmacokinetics of high-dose busulfan in children. Cancer Chemother. Pharmacol. 24(6), 386-390 (1989).

168. Heideman RL, Cole DE, Balis F, et al. Phase I and pharmacokinetic evaluation of thiotepa in the cerebrospinal fluid and plasma of pediatric patients: evidence for dosedependent plasma clearance of thiotepa. Cancer Res. 49(3), 736-741 (1989).

169. Strong JM, Collins JM, Lester C, Poplack DG. Pharmacokinetics of intraventricular and intravenous N,N',N'"-triethylenethiophosphoramide (thiotepa) in rhesus monkeys and humans. Cancer Res. 46(12 Pt 1), 6101-6104 (1986).

170. Castronovo FP, Potsaid MS, Kopiwoda S. Formulation and biological distribution of radiolabeled 1-(2-chloroethyl)-3-cyclohexyl-1-nitrosourea in an animal tumor model. Cancer Res. 40(10), 3473-3474 (1980).

171. Levin VA. Relationship of octanol/water partition coefficient and molecular weight to rat brain capillary permeability. J. Med. Chem. 23(6), 682-684 (1980).

172. Luco JM. Prediction of the brain-blood distribution of a large set of drugs from structurally derived descriptors using partial least-squares (PLS) modeling. J. Chem. Inf. Comput. Sci. 39(2), 396-404 (1999).

173. Goldwirt L, Beccaria K, Carpentier A, Farinotti R, Fernandez C. Irinotecan and temozolomide brain distribution: a focus on ABCB1. Cancer Chemother. Pharmacol. 74(1), 185-193 (2014).

174. Ostermann S, Csajka C, Buclin T, et al. Plasma and cerebrospinal fluid population pharmacokinetics of temozolomide in malignant glioma patients. Clin. Cancer Res. Off. J. Am. Assoc. Cancer Res. 10(11), 3728-3736 (2004).

175. Patel M, McCully C, Godwin K, Balis FM. Plasma and cerebrospinal fluid pharmacokinetics of intravenous temozolomide in non-human primates. J. Neurooncol. 61(3), 203-207 (2003).

176. Portnow J, Badie B, Chen M, Liu A, Blanchard S, Synold TW. The neuropharmacokinetics of temozolomide in patients with resectable brain tumors: 
potential implications for the current approach to chemoradiation. Clin. Cancer Res. Off. J. Am. Assoc. Cancer Res. 15(22), 7092-7098 (2009).

177. Reyderman L, Statkevich P, Thonoor CM, Patrick J, Batra VK, Wirth M. Disposition and pharmacokinetics of temozolomide in rat. Xenobiotica Fate Foreign Compd. Biol. Syst. 34(5), 487-500 (2004).

178. Zhou Q, Gallo JM. Differential effect of sunitinib on the distribution of temozolomide in an orthotopic glioma model. Neuro-Oncol. 11(3), 301-310 (2009).

179. Zhou Q, Guo P, Wang X, Nuthalapati S, Gallo JM. Preclinical pharmacokinetic and pharmacodynamic evaluation of metronomic and conventional temozolomide dosing regimens. J. Pharmacol. Exp. Ther. 321(1), 265-275 (2007).

180. Zhou Q, Guo P, Kruh GD, Vicini P, Wang X, Gallo JM. Predicting human tumor drug concentrations from a preclinical pharmacokinetic model of temozolomide brain disposition. Clin. Cancer Res. Off. J. Am. Assoc. Cancer Res. 13(14), 4271-4279 (2007).

181. Ettinger LJ, Chervinsky DS, Freeman AI, Creaven PJ. Pharmacokinetics of methotrexate following intravenous and intraventricular administration in acute lymphocytic leukemia and non-Hodgkin's lymphoma. Cancer. 50(9), 1676-1682 (1982).

182. Evans WE, Hutson PR, Stewart CF, et al. Methotrexate cerebrospinal fluid and serum concentrations after intermediate-dose methotrexate infusion. Clin. Pharmacol. Ther. 33(3), 301-307 (1983).

183. Heideman RL, Balis FM, Zimm S, Lester CM, Poplack DG. The effect of amitriptyline on the central nervous system penetration of methotrexate. Cancer Drug Deliv. 3(4), 219-222 (1986).

184. Lippens RJ, Winograd B. Methotrexate concentration levels in the cerebrospinal fluid during high-dose methotrexate infusions: an unreliable prediction. Pediatr. Hematol. Oncol. 5(2), 115-124 (1988).

185. Morse M, Savitch J, Balis F, et al. Altered central nervous system pharmacology of methotrexate in childhood leukemia: another sign of meningeal relapse. J. Clin. Oncol. Off. J. Am. Soc. Clin. Oncol. 3(1), 19-24 (1985).

186. Slørdal L, Jaeger R, Kjaeve J, Aarbakke J. Pharmacokinetics of 7-hydroxy-methotrexate and methotrexate in the rat. Pharmacol. Toxicol. 63(2), 81-84 (1988).

187. Thyss A, Milano G, Deville A, Manassero J, Renee N, Schneider M. Effect of dose and repeat intravenous $24 \mathrm{hr}$ infusions of methotrexate on cerebrospinal fluid availability in children with hematological malignancies. Eur. J. Cancer Clin. Oncol. 23(6), 843-847 (1987).

188. Westerhout J, van den Berg D-J, Hartman R, Danhof M, de Lange ECM. Prediction of methotrexate CNS distribution in different species - influence of disease conditions. Eur. J. Pharm. Sci. Off. J. Eur. Fed. Pharm. Sci. 57, 11-24 (2014). 
189. Baker SD, Heideman RL, Crom WR, Kuttesch JF, Gajjar A, Stewart CF. Cerebrospinal fluid pharmacokinetics and penetration of continuous infusion topotecan in children with central nervous system tumors. Cancer Chemother. Pharmacol. 37(3), 195-202 (1996).

190. Blaney SM, Cole DE, Balis FM, Godwin K, Poplack DG. Plasma and cerebrospinal fluid pharmacokinetic study of topotecan in nonhuman primates. Cancer Res. 53(4), 725-727 (1993).

191. Morgan RJ, Synold T, Mamelak A, et al. Plasma and cerebrospinal fluid pharmacokinetics of topotecan in a phase I trial of topotecan, tamoxifen, and carboplatin, in the treatment of recurrent or refractory brain or spinal cord tumors. Cancer Chemother. Pharmacol. 66(5), 927-933 (2010).

192. Straathof CS, van den Bent MJ, Loos WJ, Vecht CJ, Schellens JH. The accumulation of topotecan in 9L glioma and in brain parenchyma with and without dexamethasone administration. J. Neurooncol. 42(2), 117-122 (1999).

193. Sung C, Blaney SM, Cole DE, Balis FM, Dedrick RL. A pharmacokinetic model of topotecan clearance from plasma and cerebrospinal fluid. Cancer Res. 54(19), 51185122 (1994).

194. Zamboni WC, Lüftner DI, Egorin MJ, et al. The effect of increasing topotecan infusion from 30 minutes to 4 hours on the duration of exposure in cerebrospinal fluid. Ann. Oncol. Off. J. Eur. Soc. Med. Oncol. ESMO. 12(1), 119-122 (2001).

195. DeGregorio MW, King OY, Holleran WM, et al. Ultrafiltrate and total platinum in plasma and cerebrospinal fluid in a patient with neuroblastoma. Cancer Treat. Rep. 69(12), 1441-1442 (1985).

196. Jacobs S, McCully CL, Murphy RF, Bacher J, Balis FM, Fox E. Extracellular fluid concentrations of cisplatin, carboplatin, and oxaliplatin in brain, muscle, and blood measured using microdialysis in nonhuman primates. Cancer Chemother. Pharmacol. 65(5), 817-824 (2010).

197. Jacobs SS, Fox E, Dennie C, Morgan LB, McCully CL, Balis FM. Plasma and cerebrospinal fluid pharmacokinetics of intravenous oxaliplatin, cisplatin, and carboplatin in nonhuman primates. Clin. Cancer Res. Off. J. Am. Assoc. Cancer Res. 11(4), 1669-1674 (2005).

198. Straathof CS, van den Bent MJ, Ma J, et al. The effect of dexamethasone on the uptake of cisplatin in 9L glioma and the area of brain around tumor. J. Neurooncol. 37(1), 1-8 (1998).

199. Burgio DE, Gosland MP, McNamara PJ. Modulation effects of cyclosporine on etoposide pharmacokinetics and CNS distribution in the rat utilizing microdialysis. Biochem. Pharmacol. 51(7), 987-992 (1996).

200. Burgio DE, Gosland MP, McNamara aPJ null. Effects of P-glycoprotein modulators on etoposide elimination and central nervous system distribution. J. Pharmacol. Exp. Ther. 287(3), 911-917 (1998). 
201. Hande KR, Wedlund PJ, Noone RM, Wilkinson GR, Greco FA, Wolff SN. Pharmacokinetics of high-dose etoposide (VP-16-213) administered to cancer patients. Cancer Res. 44(1), 379-382 (1984).

202. Relling MV, Mahmoud $\mathrm{HH}$, Pui $\mathrm{CH}$, et al. Etoposide achieves potentially cytotoxic concentrations in CSF of children with acute lymphoblastic leukemia. J. Clin. Oncol. Off. J. Am. Soc. Clin. Oncol. 14(2), 399-404 (1996).

203. Zucchetti M, Rossi C, Knerich R, et al. Concentrations of VP16 and VM26 in human brain tumors. Ann. Oncol. Off. J. Eur. Soc. Med. Oncol. ESMO. 2(1), 63-66 (1991).

204. Blaney SM, Takimoto C, Murry DJ, et al. Plasma and cerebrospinal fluid pharmacokinetics of 9-aminocamptothecin (9-AC), irinotecan (CPT-11), and SN-38 in nonhuman primates. Cancer Chemother. Pharmacol. 41(6), 464-468 (1998).

205. van Asperen J, van Tellingen O, Tijssen F, Schinkel AH, Beijnen JH. Increased accumulation of doxorubicin and doxorubicinol in cardiac tissue of mice lacking mdrla P-glycoprotein. Br. J. Cancer. 79(1), 108-113 (1999).

206. Greig NH, Soncrant TT, Shetty HU, Momma S, Smith QR, Rapoport SI. Brain uptake and anticancer activities of vincristine and vinblastine are restricted by their low cerebrovascular permeability and binding to plasma constituents in rat. Cancer Chemother. Pharmacol. 26(4), 263-268 (1990).

207. Boyle FM, Eller SL, Grossman SA. Penetration of intra-arterially administered vincristine in experimental brain tumor. Neuro-Oncol. 6(4), 300-305 (2004).

208. Kellie SJ, Barbaric D, Koopmans P, Earl J, Carr DJ, de Graaf SSN. Cerebrospinal fluid concentrations of vincristine after bolus intravenous dosing: a surrogate marker of brain penetration. Cancer. 94(6), 1815-1820 (2002).

209. Eiseman JL, Eddington ND, Leslie J, et al. Plasma pharmacokinetics and tissue distribution of paclitaxel in CD2F1 mice. Cancer Chemother. Pharmacol. 34(6), 465471 (1994).

210. Heimans JJ, Vermorken JB, Wolbers JG, et al. Paclitaxel (Taxol) concentrations in brain tumor tissue. Ann. Oncol. Off. J. Eur. Soc. Med. Oncol. ESMO. 5(10), 951-953 (1994).

211. Hendrikx JJMA, Lagas JS, Wagenaar E, et al. Oral co-administration of elacridar and ritonavir enhances plasma levels of oral paclitaxel and docetaxel without affecting relative brain accumulation. Br. J. Cancer. 110(11), 2669-2676 (2014).

212. Arndt CA, Balis FM, McCully CL, Colvin OM, Poplack DG. Cerebrospinal fluid penetration of active metabolites of cyclophosphamide and ifosfamide in rhesus monkeys. Cancer Res. 48(8), 2113-2115 (1988).

213. Creaven PJ, Allen LM, Alford DA, Cohen MH. Clinical pharmacology of isophosphamide. Clin. Pharmacol. Ther. 16(1), 77-86 (1974).

214. Ninane J, Baurain R, de Kraker J, Ferster A, Trouet A, Cornu G. Alkylating activity in serum, urine, and CSF following high-dose ifosfamide in children. Cancer Chemother. Pharmacol. 24 Suppl 1, S2-6; discussion S7 (1989). 
215. Walker EJ, Su H, Shen F, et al. Bevacizumab attenuates VEGF-induced angiogenesis and vascular malformations in the adult mouse brain. Stroke J. Cereb. Circ. 43(7), 19251930 (2012).

216. Wang W, Wang EQ, Balthasar JP. Monoclonal antibody pharmacokinetics and pharmacodynamics. Clin. Pharmacol. Ther. 84(5), 548-558 (2008).

217. Chiang M-H, Chang L-W, Wang J-W, Lin L-C, Tsai T-H. Herb-drug pharmacokinetic interaction of a traditional chinese medicine jia-wei-xiao-yao-san with 5-Fluorouracil in the blood and brain of rat using microdialysis. Evid.-Based Complement. Altern. Med. ECAM. 2015, 729679 (2015).

218. Hornbeck CL, Floyd RA, Byfield JE, Griffiths JC, Frankel S, Sharp TR. Cerebrospinal fluid versus serum concentrations of 5-FU, allopurinol, and oxypurinol during treatment of metastatic brain cancer with 5-FU infusion, allopurinol, and radiation. Cancer Treat. Rep. 66(3), 571-573 (1982).

219. Kerr IG, Zimm S, Collins JM, O’Neill D, Poplack DG. Effect of intravenous dose and schedule on cerebrospinal fluid pharmacokinetics of 5-fluorouracil in the monkey. Cancer Res. 44(11), 4929-4932 (1984).

220. Dogruel M, Gibbs JE, Thomas SA. Hydroxyurea transport across the blood-brain and blood-cerebrospinal fluid barriers of the guinea-pig. J. Neurochem. 87(1), 76-84 (2003).

221. Gwilt PR, Manouilov KK, McNabb J, Swindells SS. Pharmacokinetics of hydroxyurea in plasma and cerebrospinal fluid of HIV-1-infected patients. J. Clin. Pharmacol. 43(9), 1003-1007 (2003).

222. Navarra P, Del Carmine R, Ciabattoni G, et al. Hydroxyurea: relationship between toxicity and centrally-induced adrenal activation. Pharmacol. Toxicol. 67(3), 209-215 (1990).

223. ten Tije AJ, Loos WJ, Zhao M, et al. Limited cerebrospinal fluid penetration of docetaxel. Anticancer. Drugs. 15(7), 715-718 (2004).

224. Li C-M, Lu Y, Chen J, et al. Orally bioavailable tubulin antagonists for paclitaxelrefractory cancer. Pharm. Res. 29(11), 3053-3063 (2012).

225. Breithaupt H, Pralle H, Eckhardt T, von Hattingberg M, Schick J, Löffler H. Clinical results and pharmacokinetics of high-dose cytosine arabinoside (HD ARA-C). Cancer. 50(7), 1248-1257 (1982).

226. DeAngelis LM, Kreis W, Chan K, Dantis E, Akerman S. Pharmacokinetics of ara-C and ara-U in plasma and CSF after high-dose administration of cytosine arabinoside. Cancer Chemother. Pharmacol. 29(3), 173-177 (1992).

227. van Prooijen HC, Punt K, Muus P. Cerebrospinal fluid concentrations of cytosine arabinoside during intravenous therapy with intermediate dose: a preliminary report. $\mathrm{Br}$. J. Haematol. 59(1), 188-190 (1985). 
228. Slevin ML, Piall EM, Aherne GW, Johnston A, Lister TA. The pharmacokinetics of cytosine arabinoside in the plasma and cerebrospinal fluid during conventional and highdose therapy. Med. Pediatr. Oncol. 10 Suppl 1, 157-168 (1982).

229. Wolff JE, Trilling T, Mölenkamp G, Egeler RM, Jürgens H. Chemosensitivity of glioma cells in vitro: a meta analysis. J. Cancer Res. Clin. Oncol. 125(8-9), 481-486 (1999). 


\section{Legends to figures}

Figure 1: Structure of the brain barriers. Overview in Panel A. Adapted from Saunders et al. 2013 [18] and Langlet et al. 2014 [131].

Panel B: The actors of the Blood Brain Barrier. Endothelial cells are the main actors of the BBB. Pericytes are closely attached to the endothelial cells via gap and adherens junctions. Astrocyte end-feet strongly surround the basal matrix.

Panel C. The choroid plexus and ependyma. The choroid plexus is at the interface between blood and CSF in the $3^{\text {rd }}$ and $4^{\text {th }}$ ventricles. The fenestrated endothelium is covered by tightly attached Choroid plexus epithelial cells. The ependyma surrounding the $3^{\text {rd }}$ and $4^{\text {th }}$ ventricle is constituted of a loosely attached ependymocytes contacted by astrocytes.

Panel D. The meningeal barriers. CSF in the subarachnoid space is protected by the arachnoid barrier cell layer and is isolated from brain by the pia matter. Pia matter and the arachnoid barrier also covers blood vessels.

Panel E. The circumventricular organs. Due to their particular role, circumventricular organs require a direct contact to the blood. Therefore, the BBB does not exist or is altered in these organs. However, they are isolated from the brain by a dense matrix and astrocytes/tanycytes layer. These organs are close to the $3^{\text {rd }}$ and $4^{\text {th }}$ ventricle, but a particular ependyma in these organs with tightly attached tanycytes prevent diffusion to the CSF. Tanycytes also contact the blood vessels in and out of these organs, and replace astrocytes endfeet.

\section{Figure 2: Transport mechanisms through the blood brain barrier}

Five pathways are distinguished: (i) paracellular pathway, (ii) transcellular pathway, (iii) transcytosis pathway, (iv) transport protein pathway and (v) efflux pumps pathway 
Figure 3: Left temporal glioblastoma

Panel A1, MRI T1SE weighted images; Panel A2, same panel as A1 with central necrotic area indicated in yellow; Panel B1, MRI T1SE weighted images with gadolinium infusion showing contrast enhancement; Panel B2, same panel as B1 with the tumor proliferative forehead indicated in red; Panel C1, MRI T2 FLAIR weighted images; Panel C2, same panel as C1 with the brain adjacent the tumor indicated in green. 
Table 1. Cytotoxic chemotherapeutic agents used in neuro-oncology

\begin{tabular}{|c|c|c|c|c|}
\hline Drug & $\begin{array}{c}\text { Tested as } \\
\text { monotherapy in } \\
\text { clinical trial } \\
\text { dedicated to } \\
\text { GBM patients }\end{array}$ & $\begin{array}{l}\text { CNS toxicity at high } \\
\text { dose or in direct } \\
\text { exposure to the CNS }\end{array}$ & $\begin{array}{l}\text { Currently } \\
\text { used in } \\
\text { neuro- } \\
\text { oncology }\end{array}$ & References \\
\hline Busulfan & No & Medium & ++ & {$[28]$} \\
\hline Thiotepa & No & Low-medium & ++ & [28] \\
\hline CCNU (lomustine) & Yes & Low & +++ & {$[28,132,133]$} \\
\hline $\begin{array}{l}\text { BCNU } \\
\text { (carmustine) }\end{array}$ & No & Low-medium & +++ & {$[28,42,132]$} \\
\hline ACNU (nimustine) & Yes & Medium & ++ & {$[28,69,70]$} \\
\hline Temozolomide & Yes & Low & +++ & {$[28,134-136]$} \\
\hline Methotrexate & Yes & Medium & +++ & {$[28,132,137]$} \\
\hline Topotecan & Yes & Low & - & {$[28,32,138,139]$} \\
\hline Cisplatin & No & High & $++^{*}$ & {$[28,132]$} \\
\hline Etoposide & Yes & Low-medium & ++ & {$[28,140]$} \\
\hline Irinotecan / SN-38 & Yes & Low-medium & + & {$[28,141-143]$} \\
\hline Carboplatin & Yes & Medium & ++ & {$[28,132,144-146]$} \\
\hline Doxorubicin & $\begin{array}{l}\text { No (Yes for } \\
\text { liposomal } \\
\text { form) }\end{array}$ & Medium-high & - & {$[28,108,132]$} \\
\hline Vinblastine & No & Medium & + & {$[28,132]$} \\
\hline Vincristine & No & Medium-high & ++ & {$[26,28,132]$} \\
\hline Procarbazine & Yes & Medium-high & ++ & {$[28,132,147]$} \\
\hline Paclitaxel & Yes & Medium-high & - & {$[32,132,148-150]$} \\
\hline Fotemustine & Yes & Low-medium & + & [151-154] \\
\hline $\begin{array}{l}\text { Ifosfamide / 4- } \\
\text { Hydroxyifosfamide } \\
\text { / aldoifosfamide }\end{array}$ & Yes & High & - & {$[28,132,136]$} \\
\hline Bevacizumab** & Yes & No & ++ & {$[133,155-158]$} \\
\hline 5-FluoroUracil & No & Medium-high & - & {$[28,132]$} \\
\hline Bleomycin & Yes & Low & - & {$[28,159]$} \\
\hline Hydroxyurea & Yes & Low & - & {$[28,132,160]$} \\
\hline Docetaxel & Yes & Medium-high & - & {$[28,161-163]$} \\
\hline $\begin{array}{l}\text { Cytarabine } \\
\text { (cytosine } \\
\text { arabinoside, ara-C) } \\
\text { / ara-U }\end{array}$ & No & Low & + & {$[28]$} \\
\hline
\end{tabular}

Legend: -: not commonly used in neuro-oncology; +: poorly used or used in limited or specific situations; ++: commonly used in neuro-oncology; +++: highly used in neuro-oncology; *, 
mainly in pediatric neuro-oncology; **, not a cytotoxic agent but a monoclonal antibody targeting VEGF-A used in neuro-oncology. 
Table 2. Blood brain barrier crossing: experimental data for chemotherapeutic agents used in neuro-oncology

\begin{tabular}{|c|c|c|c|c|}
\hline Drug & Species & $\begin{array}{l}\text { Normal Brain/ } \\
\text { Plasma ratio }\end{array}$ & $\begin{array}{c}\text { CSF/ } \\
\text { Plasma ratio }\end{array}$ & References \\
\hline \multirow{3}{*}{ Busulfan } & $\mathrm{H}$ & NA & $95-99 \%$ & \multirow{3}{*}{ [164-167] } \\
\hline & $\mathrm{P}$ & NA & NA & \\
\hline & $\mathrm{R}$ & $74-77 \%$ & NA & \\
\hline \multirow{3}{*}{ Thiotepa } & $\mathrm{H}$ & NA & $101 \% / 95 \% * *$ & \multirow{3}{*}[168,169]{} \\
\hline & $\mathrm{P}$ & NA & $\begin{array}{l}93 \% \text { (ventricular) } \\
113 \% \text { (lumbar) }\end{array}$ & \\
\hline & $\mathrm{R}$ & NA & NA & \\
\hline \multirow{2}{*}{$\begin{array}{l}\text { CCNU } \\
\text { (lomustine) }\end{array}$} & $\mathrm{H} / \mathrm{P}$ & NA & NA & \multirow{2}{*}[170,171]{} \\
\hline & $\mathrm{R}$ & High ; 20\% **** & NA & \\
\hline \multirow{2}{*}{$\begin{array}{l}\text { BCNU } \\
\text { (carmustine) }\end{array}$} & $\mathrm{H} / \mathrm{P}$ & NA & NA & \multirow{2}{*}[171,172]{} \\
\hline & $\mathrm{R}$ & High; $30 \%$ & NA & \\
\hline $\begin{array}{l}\text { ACNU } \\
\text { (nimustine) }\end{array}$ & $\mathrm{H} / \mathrm{P} / \mathrm{R}$ & NA & NA & \\
\hline \multirow{3}{*}{ Temozolomide } & $\mathrm{H}$ & $18 \% * ; * * *$ & $20-40 \% * *$ & \multirow{3}{*}{$\begin{array}{c}{[103,173-} \\
180]\end{array}$} \\
\hline & $\mathrm{P}$ & NA & $33 \%$ & \\
\hline & $\mathrm{R}$ & $22-41 \%$ (include $* * * *$ ) & $20-23 \% * *$ & \\
\hline \multirow{3}{*}{ Methotrexate } & $\mathrm{H}$ & NA & $0.5-2.5 \%$ & \multirow{3}{*}{ [181-188] } \\
\hline & $\mathrm{P}$ & NA & $1.5 \%$ & \\
\hline & $\mathrm{R}$ & $3 \% *-21 \%$ & $0.5 \%$ & \\
\hline \multirow{3}{*}{ Topotecan } & $\mathrm{H}$ & $\mathrm{NA}$ & $18-42 \% * *$ & \multirow{3}{*}{ [189-194] } \\
\hline & $\mathrm{P}$ & NA & $19-24 \%$ & \\
\hline & $\mathrm{R}$ & $5.5 \% * * * *$ & NA & \\
\hline \multirow{3}{*}{ Cisplatin } & $\mathrm{H}$ & NA & $3 \% * *$ & \multirow{3}{*}{ [195-198] } \\
\hline & $\mathrm{P}$ & $1-3 \% *$ & $3-5 \%$ (include $* *)$ & \\
\hline & $\mathrm{R}$ & $10 \%$ (include $* * * *$ ) & NA & \\
\hline \multirow{3}{*}{ Etoposide } & $\mathrm{H}$ & NA & $0.5-5 \% ; 9 \% * * *$ & \multirow{3}{*}{$\begin{array}{c}{[171,199-} \\
203]\end{array}$} \\
\hline & $\mathrm{P}$ & NA & NA & \\
\hline & $\mathrm{R}$ & Very low; $3-8 \% ; 36 \%$ & NA & \\
\hline \multirow{3}{*}{ Irinotecan/SN38 } & $\mathrm{H}$ & $\mathrm{NA}$ & NA & \multirow{3}{*}[173,204]{} \\
\hline & $\mathrm{P}$ & NA & $13 \% / \mathrm{ND}$ & \\
\hline & $\mathrm{R}$ & $9-13 \% / 1-6 \%$ & NA & \\
\hline \multirow{2}{*}{ Carboplatin } & $\mathrm{H} / \mathrm{R}$ & NA & NA & \multirow{2}{*}{$\begin{array}{c}{[105,196,19} \\
7]\end{array}$} \\
\hline & $\mathrm{P}$ & $2 / 3-4 \% *$ & $1-5 \%$ & \\
\hline \multirow{2}{*}{ Doxorubicin } & $\mathrm{H} / \mathrm{P}$ & NA & NA & \multirow{2}{*}[171,205]{} \\
\hline & $\mathrm{R}$ & Very low; 0-0.5\% & NA & \\
\hline \multirow{2}{*}{ Vinblastine } & $\mathrm{H} / \mathrm{P}$ & NA & NA & \multirow{2}{*}[127,206]{} \\
\hline & $\mathrm{R}$ & ND**-10\% & NA & \\
\hline & $\mathrm{H}$ & NA & ND & \\
\hline Vincristine & $\mathrm{P}$ & NA & NA & $\begin{array}{l}{[152,193,} \\
227-229]\end{array}$ \\
\hline & $\mathrm{R}$ & Very low****-18\% & NA & \\
\hline & $\mathrm{H} / \mathrm{P}$ & NA & $\mathrm{NA}$ & {$[171]$} \\
\hline Procarbazine & $\mathrm{R}$ & medium & NA & {$[1 / 1]$} \\
\hline Paclitaxel & $\mathrm{H}$ & $\mathrm{ND} * * * *$ & $\mathrm{ND}$ & [209-211] \\
\hline
\end{tabular}




\begin{tabular}{|c|c|c|c|c|}
\hline & $\mathrm{P}$ & NA & NA & \\
\hline & $\mathrm{R}$ & $\mathrm{ND}-\approx 19 \%$ & NA & \\
\hline \multirow{2}{*}{ Fotemustine } & $\mathrm{H}$ & NA & $17-30 \%$ & \multirow{2}{*}[152]{} \\
\hline & $\mathrm{P} / \mathrm{R}$ & NA & NA & \\
\hline \multirow{3}{*}{$\begin{array}{l}\text { Ifosfamide / 4- } \\
\text { Hydroxyifosfami } \\
\text { de } \\
\text { aldoifosfamide }\end{array}$} & $\mathrm{H}$ & NA & 23- 53\% / NA / NA & \multirow{3}{*}{ [212-214] } \\
\hline & $\mathrm{P}$ & $\mathrm{NA}$ & NA / 13\% / NA & \\
\hline & $\mathrm{R}$ & NA & NA & \\
\hline \multirow{3}{*}{ Bevacizumab } & $\mathrm{H}$ & $0.2 \%$ (general for $\operatorname{IgG}$ ) & NA & \multirow{3}{*}[215,216]{} \\
\hline & $\mathrm{P}$ & NA & NA & \\
\hline & $\mathrm{R}$ & ND & NA & \\
\hline \multirow{3}{*}{ 5-FluoroUracil } & $\mathrm{H}$ & NA & ND-low** & \multirow{3}{*}{$\begin{array}{c}{[171,217-} \\
219]\end{array}$} \\
\hline & $\mathrm{P}$ & NA & $\begin{array}{l}48 \% \text { (bolus); } 11-20 \% \\
\text { (infusion, depending } \\
\text { upon infusion rate) }\end{array}$ & \\
\hline & $\mathrm{R}$ & low $-18^{*}$ & NA & \\
\hline \multirow{2}{*}{ Bleomycin } & $\mathrm{H} / \mathrm{P}$ & NA & NA & \multirow{2}{*}[171]{} \\
\hline & $\mathrm{R}$ & Very low & NA & \\
\hline \multirow{3}{*}{ Hydroxyurea } & $\mathrm{H}$ & NA & $33 \%$ (HIV patient) & \multirow{3}{*}{ [220-222] } \\
\hline & $\mathrm{P}$ & NA & NA & \\
\hline & $\mathrm{R}$ & $9-25 \%$ & $6 \%$ & \\
\hline \multirow{3}{*}{ Docetaxel } & $\mathrm{H}$ & NA & $0-9 \% * *$ & \multirow{3}{*}{$\begin{array}{c}{[83,211,223} \\
, 224]\end{array}$} \\
\hline & $\mathrm{P}$ & NA & NA & \\
\hline & $\mathrm{R}$ & $4.4-\approx 8 \% ; 29-35 \%$ & NA & \\
\hline \multirow{2}{*}{$\begin{array}{l}\text { Cytarabine } \\
\text { (cytosine } \\
\text { arabinoside, ara- } \\
\text { C) / ara-U }\end{array}$} & $\mathrm{H}$ & NA & $\begin{array}{c}\text { 3-15\% / 15-25\% } \\
\text { (include **) }\end{array}$ & \multirow{2}{*}{ [225-228] } \\
\hline & $\mathrm{P} / \mathrm{R}$ & NA & NA & \\
\hline
\end{tabular}

Legend: $\mathrm{H}$, human; $\mathrm{P}$, primate; $\mathrm{R}$, rodent -mice or rat-; *, extracellular fluid by microanalysis; **, CNS involvement; ***, Brain adjacent to tumor; ****, Normal brain of animals/patients with brain tumors. ND, not detected. Data above $100 \%$ indicate accumulation of the drug, or a faster clearance in the plasma than in the brain or CSF. Many drugs also showed a similar effect with large scales $-e$.g. methotrexate, paclitaxel, docetaxel-. We tried to show penetration with minimum impact of accumulation or differential clearance. 
Table 3. Parameters used to predict crossing of the blood brain barrier by chemotherapeutic agents

\begin{tabular}{|c|c|c|c|c|c|c|c|c|c|c|c|}
\hline Drug & $\begin{array}{c}\text { M. } \\
\text { weight }\end{array}$ & $\begin{array}{c}\text { Ex- } \\
\text { LogP }\end{array}$ & $\begin{array}{c}\text { Polar } \\
\text { SA }\end{array}$ & $\begin{array}{c}\mathrm{P} . \\
\text { charges }\end{array}$ & $\begin{array}{c}\text { Rot. } \\
\text { bound }\end{array}$ & $\begin{array}{c}\text { HB } \\
\text { acceptor }\end{array}$ & $\begin{array}{c}\text { HB } \\
\text { donor }\end{array}$ & $\begin{array}{l}\text { Protein } \\
\text { binding }\end{array}$ & P-gp & Rule of 5 & $\begin{array}{c}\text { In silico } \\
\text { prediction* }\end{array}$ \\
\hline Busulfan & 246 & -0.5 & $87-104$ & 0 & 7 & 4 & 0 & $32-79 \%$ & No & Yes & Yes \\
\hline Thiotepa/tepa & $189 / 173$ & $0.5 / \mathrm{NA}$ & $9-51 / 36$ & $0 / 0$ & $3 / 3$ & $3-1 / 1$ & $0 / 0$ & NA/NA & $\mathrm{No} / \mathrm{NA}$ & Yes/Yes & Yes \\
\hline CCNU (lomustine) & 234 & 2.8 & 62 & 0 & 4 & 2 & 1 & $50 \%$ & No & Yes & Yes \\
\hline BCNU carmustine) & 214 & 1.5 & 62 & 0 & 5 & 2 & 1 & $80 \%$ & $\mathrm{No}$ & Yes & Yes \\
\hline ACNU (nimustine) & 273 & NA & 114 & 0 & 5 & NA & $\mathrm{NA}$ & NA & $\mathrm{NA}$ & Yes & Yes \\
\hline Temozolomide & 194 & -2.8 & 106 & 0 & 1 & 5 & 1 & $15 \%$ & No & Yes & Yes \\
\hline Methotrexate & 454 & -1.9 & 211 & -2 & 9 & 12 & 5 & $50 \%$ & Yes & No & No \\
\hline Topotecan & 421 & 0.8 & 103 & 0 & 3 & 6 & 2 & $35 \%$ & Yes & Yes & No \\
\hline Cisplatin & 298 & -2.2 & $\mathrm{NA}$ & 0 & 1 & 5 & 1 & $90 \%($ Free P) & No & Yes & Yes \\
\hline Etoposide & 589 & 0.6 & 161 & 0 & 5 & 12 & 3 & $97 \%$ & Yes & No & No \\
\hline Irinotecan / SN-38 & $587 / 392$ & $3.2 / \mathrm{NA}$ & $113 / 100$ & $1 / 0$ & $5 / 2$ & $6 / 5$ & $1 / 2$ & $30-68 \% / \mathrm{NA}$ & Yes/Yes & $\mathrm{No} / \mathrm{Yes}$ & $\mathrm{No} / \mathrm{No}$ \\
\hline Carboplatin & 371 & NA & NA & 0 & 0 & 2 & 0 & $90 \%$ (Free P) & No & Yes & Yes \\
\hline Doxorubicin & 544 & 1.3 & 206 & 1 & 5 & 12 & 6 & $74-76 \%$ & Yes & No & No \\
\hline Vinblastine & 811 & 3.7 & 154 & 2 & 10 & 9 & 3 & $98-99 \%$ & Yes & No & No \\
\hline Vincristine & 825 & 2.8 & 171 & 2 & 10 & 9 & 3 & $\sim 75 \%$ & Yes & No & No \\
\hline Procarbazine & 221 & 0.1 & 53 & 0 & 5 & 3 & 3 & NA & No & Yes & Yes \\
\hline Paclitaxel & 854 & 3.0 & 221 & 0 & 14 & 10 & 4 & $89-98 \%$ & Yes & No & No \\
\hline Fotemustine & 316 & NA & 107 & 0 & 9 & 3 & 1 & NA & No & Yes & Yes \\
\hline $\begin{array}{l}\text { Ifosfamide / 4- } \\
\text { Hydroxyifosfamide } \\
\text { / aldoifosfamide }\end{array}$ & $\begin{array}{c}261 / \\
277 / \\
277 \\
\end{array}$ & $\begin{array}{c}0.9 \text { / NA } \\
\text { / NA }\end{array}$ & $\begin{array}{c}51 / 71 / \\
77\end{array}$ & $0 / 0 / 0$ & $\begin{array}{c}5 / 5 / \\
10\end{array}$ & $2 / 3 / 3$ & $1 / 2 / 2$ & $\begin{array}{c}\text { Low / NA / } \\
\text { NA }\end{array}$ & $\begin{array}{c}\text { No / NA } \\
\text { / NA }\end{array}$ & $\begin{array}{c}\text { Yes / Yes } \\
\text { / Yes }\end{array}$ & $\begin{array}{c}\text { Yes / Yes / } \\
\text { Yes OR } \\
\text { No*** } \\
\end{array}$ \\
\hline Bevacizumab & 149,000 & NA & NA & NA & NA & NA & NA & NA & $\mathrm{NA}$ & No & NA \\
\hline $5-\mathrm{FU} * *$ & 130 & -0.89 & 58.2 & 0 & 0 & 2 & 2 & $8-12 \%$ & No & Yes & Yes \\
\hline Bleomycin & 1415 & NA & 627 & 2 & 36 & 28 & 20 & $1 \%$ & Yes & Yes**** & No \\
\hline Hydroxyurea & 76 & -1.8 & 75 & 0 & 0 & 2 & 3 & NA & No & Yes & Yes \\
\hline Docetaxel & 808 & 2.4 & 224 & 0 & 13 & 10 & 5 & $97 \%$ & Yes & No & No \\
\hline
\end{tabular}




\begin{tabular}{|l|c|c|c|c|c|c|c|c|c|c|c|}
\hline $\begin{array}{l}\text { Cytarabine } \\
\text { (cytosine } \\
\text { arabinoside, ara-C) / } \\
\text { ara-U }\end{array}$ & $\begin{array}{c}243 / \\
244\end{array}$ & $\begin{array}{c}-2.8 / \\
\text { NA }\end{array}$ & $\begin{array}{c}129 / \\
119\end{array}$ & $0 / 0$ & $2 / 2$ & $7 / 6$ & $4 / 4$ & $13 \% /$ NA & No / NA & Yes / Yes & $\begin{array}{c}\text { Yes OR No } \\
/ \text { Yes OR } \\
\text { No }\end{array}$ \\
\hline
\end{tabular}

Legend: M weight, Molecular weight (g/mol); Ex-LogP, experimental LogP; Polar SA, polar surface area $\left(\AA^{2}\right)$; P charges, physiological charges; Rot. Bound, Rotatable bound count; HB acceptor, hydrogen bond acceptor count; HB donor, hydrogen bond donor count; Prot. binding, Protein binding; P-gp, P-glycoprotein substrat; *, http://www.cbligand.org/BBB/index.php; NA, not available on the used databases; Free P, free platinum; **, no information for active forms after hepatic metabolism; ***, depending on the algorithm; **** found in database, but inconsistent with the size of the molecule. Data obtained from chEMBL (https://www.ebi.ac.uk/chembl/) and drugbank (http://www.drugbank.ca/). 
Table 4. In vitro efficacy of chemotherapeutic cytotoxic agent used in neuro-oncology

\begin{tabular}{|c|c|c|c|}
\hline Drug & GI50 & IC50 & LC50* \\
\hline Busulfan & $234000 \mathrm{nM}^{\mathrm{U} 251}$ & NA & NA \\
\hline Thiotepa / Tepa & $58749 \mathrm{nM}^{\mathrm{U} 251} / \mathrm{NA}$ & NA / NA & NA / NA \\
\hline CCNU (lomustine) & $31550 \mathrm{nM}^{\mathrm{U} 251}$ & NA & $328000 \mathrm{nM}$ \\
\hline BCNU (carmustine) & $52119 \mathrm{nM}^{\mathrm{U} 251}$ & $15000 \mathrm{nM}^{\mathrm{U} 251}$ & $173000 \mathrm{nM}$ \\
\hline ACNU (nimustine) & NA & NA & $179000 \mathrm{nM}$ \\
\hline Temozolomide & $100000 \mathrm{nM}^{\mathrm{U} 251}$ & $250000 \mathrm{nM}^{\mathrm{U} 251} ; 49000 \mathrm{nM}^{\mathrm{U} 87}$ & NA \\
\hline Methotrexate & $92 \mathrm{nM}^{\mathrm{U} 251}$ & NA & $2400 \mathrm{nM}$ \\
\hline Topotecan & $18 \mathrm{nM}^{\mathrm{U} 251}$ & $60 \mathrm{nM}-3000^{\mathrm{U} 251} ; 160 \mathrm{nM}^{\mathrm{U} 87}$ & NA \\
\hline Cisplatin & $1918.67 ; 100000 \mathrm{nM}^{\mathrm{U} 251}$ & $\begin{array}{l}490-16193.6 \mathrm{nM}^{\mathrm{U} 87} ; 11580.08 \\
\mathrm{nM}^{\mathrm{U} 251}\end{array}$ & $3670 \mathrm{nM}$ \\
\hline Etoposide & NA & $\begin{array}{l}500-25000 \quad \mathrm{nM}^{\mathrm{U} 251 / \mathrm{U} 373} ; 145 \\
12400 \mathrm{nM}^{\mathrm{U87}} ; 14880 \mathrm{nM}(8,76 \\
\mu \mathrm{g} / \mathrm{mL})\end{array}$ & NA \\
\hline Irinotecan / SN-38 & $3741 \mathrm{nM}^{\mathrm{U} 251} / 1 \mathrm{nM}^{\mathrm{U} 251}$ & NA / NA & NA / NA \\
\hline Carboplatin & $68076.94 \mathrm{nM}^{\mathrm{U} 251}$ & NA & $80000 \mathrm{nM}$ \\
\hline Doxorubicin & $40-125 \mathrm{nM}^{\mathrm{U} 251}$ & 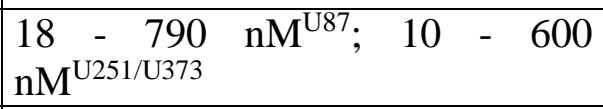 & $500 \mathrm{nM}$ \\
\hline Vinblastine & $0.7 \mathrm{nM}^{\mathrm{U} 251}$ & $5,02-8.1 \mathrm{nM}^{\mathrm{U} 251} ; 1-29.98 \mathrm{nM}^{\mathrm{U} 87}$ & $240 \mathrm{nM}$ \\
\hline Vincristine & $132 \mathrm{nM}^{\mathrm{U} 251}$ & NA & $80 \mathrm{nM}$ \\
\hline Procarbazine & $336512 \mathrm{nM}^{\mathrm{U} 251}$ & NA & NA \\
\hline Paclitaxel & $20 \mathrm{nM}^{\mathrm{U} 87} ; 3-3.98 \mathrm{nM}^{\mathrm{U} 251}$ & $80-90000 \mathrm{nM}^{\mathrm{U} 87} ; 30-128 \mathrm{nM}^{\mathrm{U} 251}$ & LC90 $7.2 \mathrm{nM}$ \\
\hline Fotemustine & NA & NA & NA \\
\hline
\end{tabular}




\begin{tabular}{|l|l|l|l|}
\hline $\begin{array}{l}\text { Ifosfamide / 4-Hydroxyifosfamide } \\
\text { / aldoifosfamide }\end{array}$ & $310456 \mathrm{nM}^{\mathrm{U} 251} / \mathrm{NA} / \mathrm{NA}$ & $\mathrm{NA} / \mathrm{NA} / \mathrm{NA}$ & NA / NA / NA \\
\hline Avastin & $\mathrm{NA}$ & $\mathrm{NA}$ & $\mathrm{NA}$ \\
\hline 5-FU & $912.01 \mathrm{nM}^{\mathrm{U} 251}$ & $\mathrm{NA}$ & $\mathrm{NA}$ \\
\hline Bleomycin & $\mathrm{NA}$ & $4363.14 \mathrm{nM}^{\mathrm{U} 251} ; 11057.16 \mathrm{nM}^{\mathrm{U} 87}$ & $\mathrm{NA}$ \\
\hline Hydroxyurea & $580764.42 \mathrm{nM}^{\mathrm{U} 251}$ & $\mathrm{NA}$ & $\mathrm{NA}$ \\
\hline Docetaxel & $10 \mathrm{nM}^{\mathrm{U} 251}$ & $2.5-25647 \mathrm{nM}^{\mathrm{U} 251} ; 3.55 \mathrm{nM}^{\mathrm{U} 87}$ & $\mathrm{NA}$ \\
\hline $\begin{array}{l}\text { Cytarabine }(\text { cytosine } \text { arabinoside, } \\
\text { ara-C) } / \text { ara-U }\end{array}$ & $\mathrm{NA} / \mathrm{NA}$ & $\begin{array}{l}1129.99 \mathrm{nM}^{\mathrm{U} 251} ; 1742.57 \mathrm{nM}^{\mathrm{U} 87} / \\
\mathrm{NA}\end{array}$ & NA / NA \\
\hline
\end{tabular}

Legend : GI50, drug concentration inducing 50\% of growth inhibition; IC50, drug concentration inducing 50\% of inhibition; LC50, drug concentration inducing $50 \%$ of cell death ; *, median LC50 obtained from multiple glioma cell lines [229]. Data obtained from chEMBL (https://www.ebi.ac.uk/chembl/) 
Figure 2

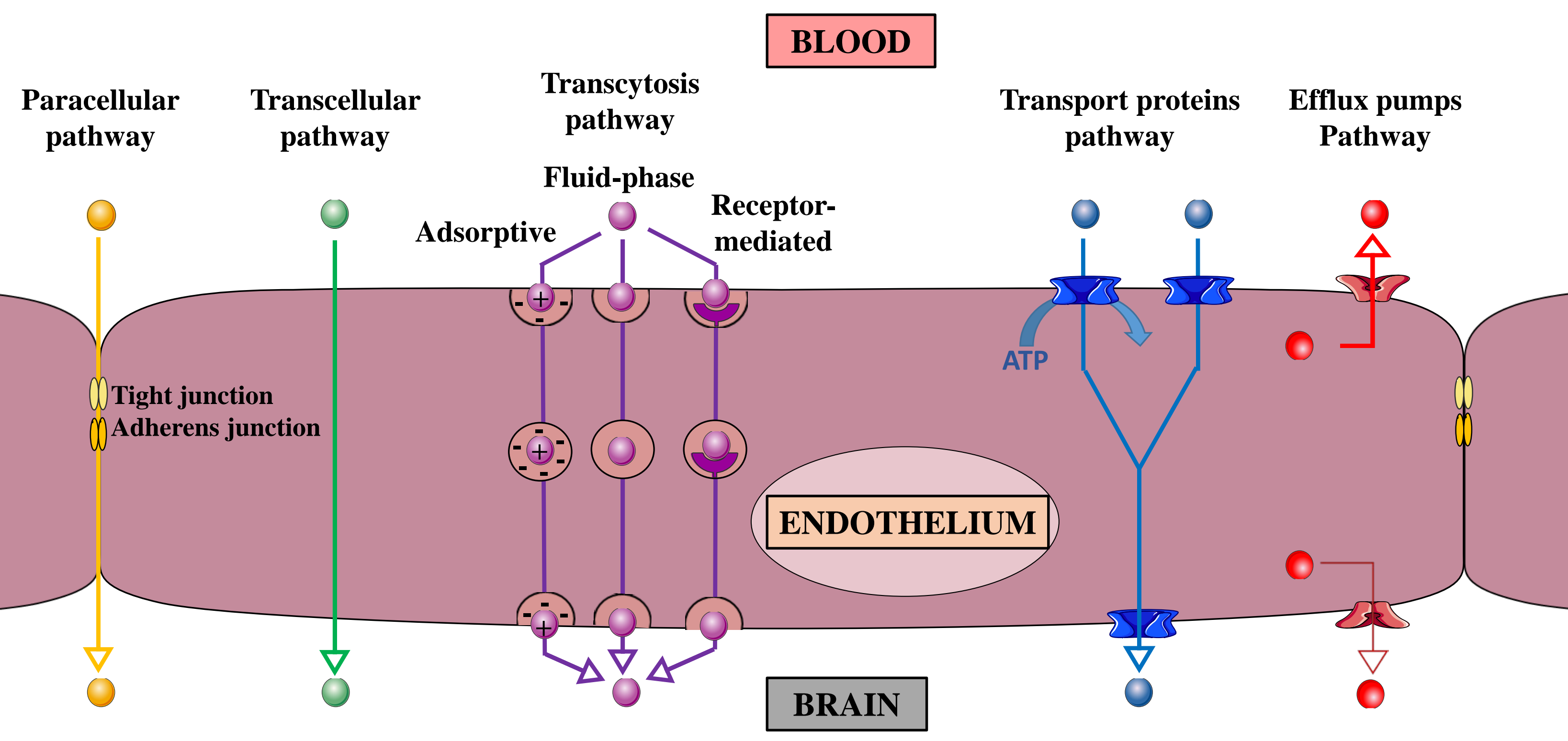


Figure 3
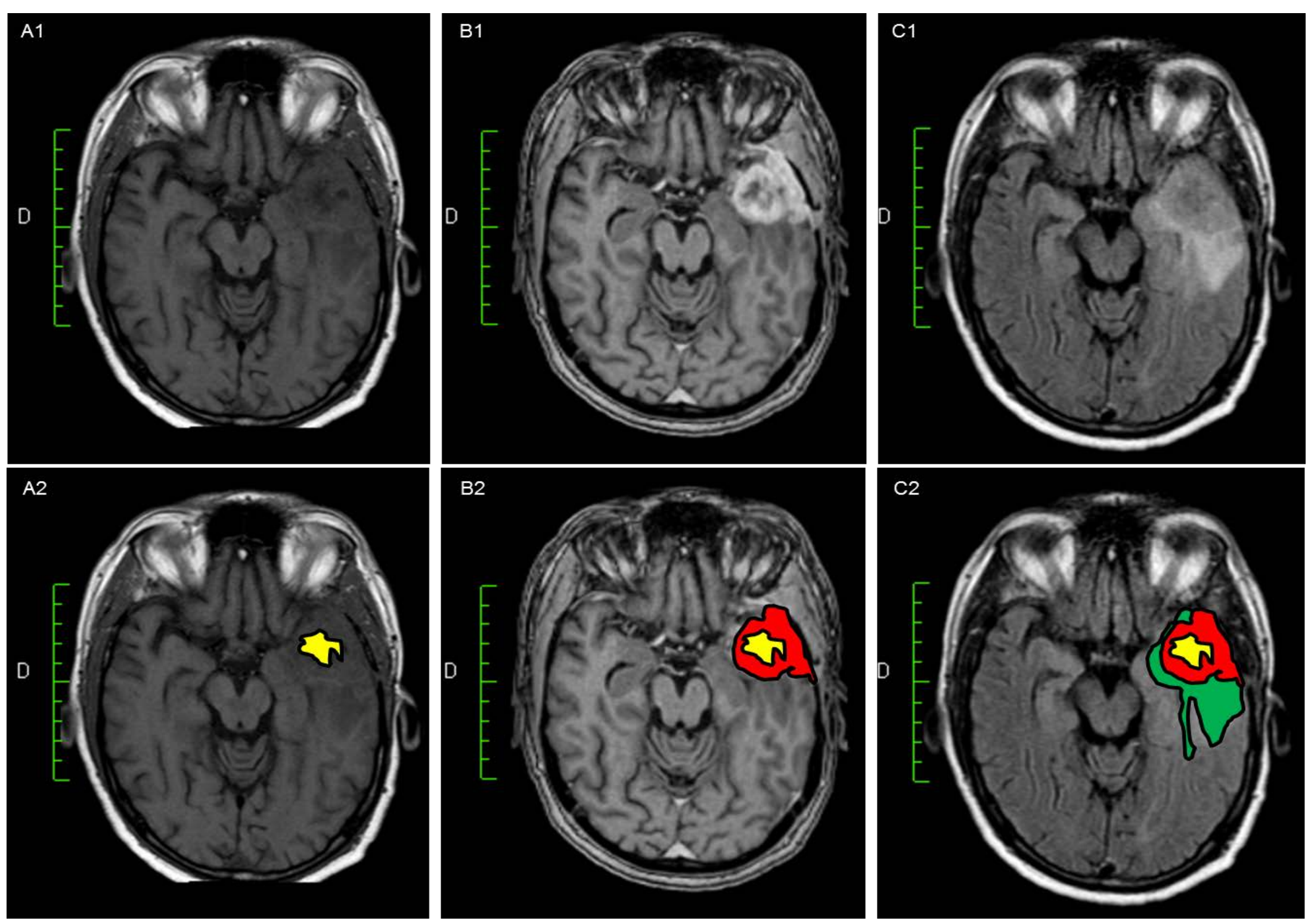